\title{
Wanneer een twee word: 'n Perspektief op resente gebeure in die Nederduitsch Hervormde Kerk van Afrika
}

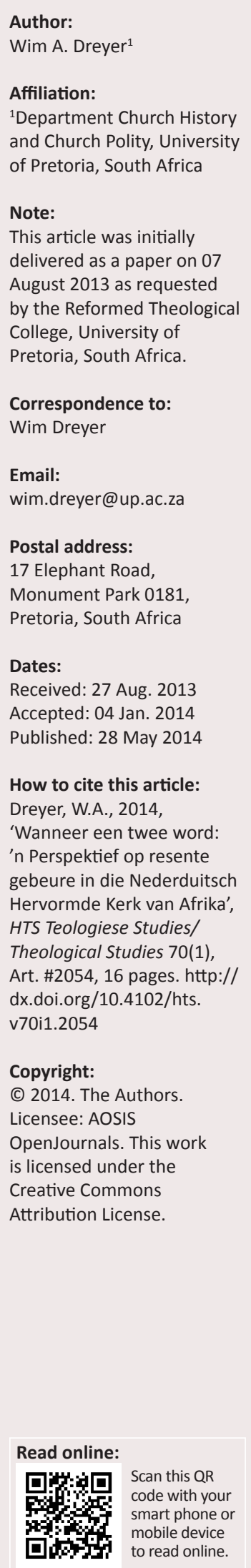

When one becomes two: A perspective on recent events in the Netherdutch Reformed Church of Africa. On 28 July 201313 congregations of the Netherdutch Reformed Church of Africa (Nederduitsch Hervormde Kerk van Afrika) declared themselves independent and constituted as the 'Geloofsbond van Hervormde Gemeentes'. This contribution examines the recent historical background to this event as well as several contributing factors such as the role of the media, the role of organisations, differences in theology as well as ideological differences. The conclusion is reached that a tension-filled discourse between confessional and critical theology, linked to clear ideological views, were the main contributing factors to divisions in the church. The contribution concludes with a discussion of some implications of these events from the perspective of church polity.

\section{Inleidende opmerkings}

Die Hervormde Teologiese Kollege het my gevra om tydens hierdie openbare lesing aandag te gee aan die resente geskiedenis van die Nederduitsch Hervormde Kerk van Afrika (hierna: Hervormde Kerk). Dié versoek hou verband met die stigting van 'n organisasie met die naam steedsHervormers in 2012 en die Bond van Onafhanklike Hervormde Kerke op 26 Januarie 2013 te Gemeente Meyerspark, wat op 28 Julie 2013 formeel gekonstitueer het as die Geloofsbond van Hervormde Gemeentes. Met hierdie gebeure het kerkskeuring vir die Hervormde Kerk ' $n$ werklikheid geword.

'n Weergawe van die gebeure op 26 Januarie 2013 is op die webblad van die steedsHervormers geplaas (steedsHervormers 2013). In die verklaring van die Geloofsbond staan onder andere:

Die Onafhanklike/Selfstandige gemeentes teenwoordig, het 'n Bond van onafhanklike gemeentes gestig met ' $n$ ope uitnodiging aan ander Onafhanklike/Selfstandige gemeentes om aan te sluit. Die besluit is eenparig geneem. Die Bond van Onafhanklike Hervormde kerke sal tydens hul eerste vergadering besluit oor teologiese opleiding, 'n naam, embleem en ander sake. Daar is reeds konsensus oor teologiese sake.

Om 'n geskiedenis van resente gebeure te skryf is om verskeie redes besonder moeilik. ' $n$ Soortgelyke poging is 'n artikel wat in 2011 in Historia verskyn het, wat die resente geskiedenis van die Nederduitse Gereformeerde (NG) Kerk ten opsigte van die kerk se besluite oor apartheid en die afskeiding van die Afrikaanse Protestantse Kerk beskryf (vgl. Van der Merwe \& Oelofse 2011; kyk ook Van Butselaar 2001:150-168). Die skrywers van die artikel het die voordeel van groter afstand (1982 - dus 30 jaar) en kan groter aanspraak maak op objektiwiteit. In hierdie bydrae, waar dit om werklik resente gebeure gaan, is dit moeiliker om objektief oor bepaalde gebeure te oordeel.

Dit is opvallend dat terminologie wat 30 jaar gelede in die NG Kerk gebruik is, bykans identies is aan dit wat die afgelope tyd in die Hervormde Kerk gehoor word. In die volgende aanhaling word terminologie beklemtoon wat identies in beide gevalle benut word:

Die Voortsettingskomitee het uiteindelik 'n Beswaarskrif die lig laat sien, getiteld Geloof en Protes - 'n antwoord namens beswaarde lidmate op sekere aspekte van Kerk en Samelewing. ... Daar word gekies om 'n nuwe kerk te help stig, 'n kerk wat staan by die Bybel as God se onfeilbare Woord, 'n kerk wat ook staan by die Belydenisskrifte as betroubare samevatting van die waarhede van die Bybel. ... Die NG Kerk is ook onder druk geplaas deur 'n ander groep in eie geledere, naamlik die NG Geloofsbond wat deur die teoloog en voormalige voorsitter van die Afrikaner Broederbond (AB), prof. Carel Boshoff, gelei is. Die NG Geloofsbond was 'n drukgroep binne die NGK wat gepoog het om die besluite wat tydens die AS van 1986 geneem is, te herroep. (Van der Merwe \& Oelofse 2010: 10, [outeur se beklemtoning])

Die kerklike afskeiding in die Hervormde geledere het 'n lang aanloop gehad. Uiteraard is dit onmoontlik om dit volledig te behandel en kan slegs 'n gereduseerde beeld aangebied word, met die moontlike beskuldiging dat dit nie 'die waarheid' is nie. Paul Ricoeur (2004) het daarop gewys dat daar ' $n$ spanningsvolle en komplekse verhouding bestaan tussen dit wat ons individueel en kollektief onthou; dat hierdie herinneringe vir geskiedskrywing uiters belangrik is maar dat 
dit tegelykertyd net voorlopig kan wees. Elke verhaal wat ons vertel, kan altyd weer op 'n ander manier vertel en gekorrigeer word. Daarom is enige beskrywing van onlangse gebeure per definisie voorlopige indrukke wat in die toekoms gekorrigeer móét word. Dit geld ook ten opsigte van hierdie bydrae.

In geskiedskrywing gaan dit om meer as 'die waarheid', veral as 'die waarheid' verstaan word as 'n absolute korrelasie tussen gebeure en die beskrywing daarvan, of as 'n objektiewe en foutlose beskrywing van die verlede. Geskiedskrywing gaan in die eerste plek om singewing (Dreyer 1974:215-239). Wanneer ons singewend met die verlede besig is, vra ons nie nét wat gebeur nie, maar ons vra óók: waarom gebeur dit? Hierdie bydrae moet gesien word as 'n poging om sin te maak van gebeure wat 'n traumatiese effek op die Hervormde Kerk gehad het.

Vanuit die geledere van die Geloofsbond is die antwoord op die waarom vraag ongekompliseerd en daarom vir baie lidmate aantreklik: Die Hervormde Kerk duld liturgiese vernuwing; die Hervormde Kerk duld leervryheid by predikante en dosente; die gesag van die Skrif en Belydenisskrifte word bevraagteken; die Kommissie van die Algemene Kerkvergadering (AKV) pas nie leertug toe nie en die AKV se besluite oor apartheid veroordeel ons voorgeslagte tot ketters en trek daarmee 'n streep deur die gedagte van 'n volkskerk. In kort: Die Hervormde Kerk het die pad byster geraak en daarom is 'n skeiding van weë onafwendbaar.

Uiteraard is daar ook ander antwoorde en perspektiewe. Die gebeure van die afgelope tyd vertoon 'n uiters komplekse beeld. In 'n poging om daarvan sin te probeer maak, word eers ' $n$ lengtesnit aangebied en dan, aan die hand van 'n paar temas, word die volgende dieptesnitte gemaak:

- Die rol van die media

- Die rol van organisasies

- Uiteenlopende teologiese denke

- Ideologiese verskille

- Enkele kerkregtelike opmerkings.

\section{Aanleidende gebeure (lengtesnit)}

Reeds 60 jaar gelede, met die aanvaarding van die 1951 Kerkwet wat bepaal het dat slegs blankes lidmaat van die Hervormde Kerk mag wees, was dit duidelik dat daar verskillende denkrigtings in die Hervormde Kerk teenwoordig was. Predikante soos A.S. Geyser, A. van Selms, C.J. Labuschagne, J.A.A.A. Stoop en M.J. Redelinghuys het hulle teen die rasklousule in Artikel III uitgespreek. Die saak is op die spits gedryf na die Cottesloe beraad van 1960, waartydens Geyser en Van Selms 'n minderheidsrapport aangebied het wat apartheid ten sterkste veroordeel het.

Beide Geyser en Van Selms was internasionaal bekend as bekwame Bybelwetenskaplikes. Geyser is in 1946, op 27-jarige ouderdom, as professor aan die Universiteit van Pretoria aangestel. Sy nagraadse studies in Aramees, Siries, Grieks, Latyn en Frans het aan hom besondere teksvaardighede gegee. In 1949 het hy in Parys aan die Sorbonne navorsing gedoen en gedoseer oor die 'Kerk in die Nuwe Testament'. In dieselfde jaar is hy deur die pous genooi om deel te neem aan opgrawings onder die Petruskerk in Rome. In 1952 word hy buitengewone dosent in Nuwe Testament aan die Universiteit Utrecht.

Tydens hierdie besoek aan Europa kom hy onder die invloed van leidingewende teoloë in die ekumeniese beweging. Na sy terugkeer uit Europa het Geyser toenemend krities gestaan teenoor die teologiese begronding van apartheid en het hy betrokke geraak by organisasies wat hulle beywer het vir die beëindiging van apartheid. In hierdie tyd het proff. A.S. Geyser en A.D. Pont in geskrifte, kerklike en openbare media asook vergaderings besonder skerp van mekaar verskil. Dit het gelei tot ' $n$ lastersaak waar die hof aan Pont opdrag gegee het om aan Geyser skadevergoeding te betaal.

In 1961 is 'n klag deur drie studente (o.a. H.G. van der Westhuizen) teen Geyser ingedien, wat daarop neergekom het dat hy ' $n$ afwykende Christologie huldig, op grond van sy eksegese van Filippense 2. In Mei 1962 is hy deur die Kommissie van die AKV skuldig bevind aan dwaalleer en is hy versoek om sy leerstoel te ontruim. Nadat hy'n aanstelling aan die Universiteit van die Witwatersrand ontvang het, het hy op 31 Julie 1962 sy bedanking as predikant van die Hervormde Kerk aangekondig. Hy is onmiddellik deur Van Selms gevolg.

Verskil van mening oor apartheid - Artikel III - volkskerk en teologiese opleiding het die afgelope 50 jaar op elke Algemene Kerkvergadering na vore gekom. In dokumente is gereeld geïnsinueer dat die sogenaamde 'Bybelwetenskaplikes' 'n afwykende Christologie huldig. So onlangs as 30 April 2013 skryf A.D. Pont (2013a) op Facebook dat die maagdelike geboorte van Jesus 'n ontwyfelbare historiese feit is en vra dan: 'Waarom put geleerde Bybelwetenskaplikes hulleself so uit om te bewys dat God se beloftes nie waar kan wees nie?'

Ek is van mening dat die diskoers van die afgelope 50 jaar getipeer kan word as 'n spanningsvolle gesprek tussen konfessionele en kritiese teologie. Onderliggend aan die diskoers, was ook die vraag: Wat is Hervormde teologie? Die term 'Bybels-reformatoriese teologie' het as sambreelterm daarin geslaag om verskillende teologiese strominge in die Hervormde Kerk tydelik bymekaar te hou. Die gebeure sedert die 69e AKV het die uiteenlopende denke in die Hervormde Kerk weer na vore gebring en aangetoon dat 'n term soos 'Bybels-reformatories' nie sondermeer daarin slaag om konsensus te bewerkstellig nie.

Die ruimte ontbreek om hierdie tema volledig te ontgin. Ek gaan dus volstaan deur meer onlangse gebeure kortliks te bespreek. 


\section{Eietydse getuienis op Hervormingsondag (1995)}

Op 04 November 1995 het 'n groep predikante en lidmate van die Hervormde Kerk onder leiding van 'n 'loodskomitee' (A.D. Pont, H.G. van der Westhuizen, G.C. van Staden, J.J. Steenkamp, S. Gregan, H.J. Botes en J.H. Breytenbach) die sogenaamde 'Eietydse Getuienis op Hervormingsondag' uitgereik. Die Getuienis het die bedoeling gehad om 'n 'vurk in die pad' aan te dui (Steenkamp 1995:3). Die vurk in die pad van die Hervormde Kerk is aangedui as uiteenlopende teologiese rigtings.

In die voorwoord van die Getuienis (Steenkamp 1995) is daar ook 'n verwysing na 'Die Verbond' - 'n liggaam wat geskep is om konfessionele teologie in die Hervormde Kerk te bevorder. In die voorwoord lees ons:

Die een saak wat ons tot 'n eenheid saamgesnoer het, was ons aanvaarding van die belydenisskrifte van die kerk. Dit was die enkele saambindende faktor in wat ons die Bybels-reformatoriese teologie noem. ... Dit is duidelik dat daar verskillende teologiese strominge (nie net twee nie) in ons kerk bestaan. Waar die belydenisskrifte in die verlede die eenheid bewaar het, blyk dit nie meer [die geval] te wees nie. (geen bladsy beskikbaar)

Die Verbond het verskeie vergaderings gehou, waarheen lidmate uitgenooi is. Die Kommissie van die AKV het die saak probeer beredder deur die Predikantevergadering van 1996 te vervroeg, waar verskillende standpunte gestel is. Dit het waarskynlik die uiteenlopende teologiese standpunte net verder beklemtoon.

In die teks van die Getuienis (Steenkamp 1995:5-10) word die stelling gemaak dat die afwykende teologiese tendense in die Hervormde Kerk dringend reggestel moet word. Die Verbond was van mening dat sommige Hervormde teoloë nie die Skrif as die Woord van God beskou nie; die maagdelike geboorte en liggaamlike opstanding van Christus ontken en nie meer die Belydenisskrifte onderskryf nie.

In 1994 het 'n nuwe politieke bedeling in Suid-Afrika aangebreek. Nelson Mandela is ingesweer as president van die Republiek van Suid-Afrika. Die Hervormde Kerk word in die Getuienis verkwalik vir haar onderdanigheid en onvermoë om teenoor die nuwe owerheid te getuig. Ten slotte verwerp die Getuienis die humanistiese 'eenheidsideologie' wat ras-, volk- en kultuurgemengde gemeentes op die kerk wil afdwing (Steenkamp 1995:9). Die lidmate van die Hervormde Kerk word opgeroep om die diepgaande teologiese skeiding in die kerk raak te sien, die humanisme en ander afwykende tendense in die kerk te bestry en te bid dat dié wat daardeur bekoor word, tot bekering sal kom.

In 'n ongepubliseerde 'Inligtingstuk 2012' van die steedsHervormers (2012c) wat in my besit is, word op bladsy 2 'n diagram aangebied wat die handelinge van die huidige Geloofsbond ten nouste verbind aan die Verbond van 1995/1996. Die organiese, teologiese en historiese verbintenis tussen die HCM Fourie Vriendekring, Verbond, steedsHervormers, Geloofsbond van Onafhanklike Hervormde
Kerk en Geloofsbond van Hervormde Gemeentes kan sonder moeite aangetoon word (vgl. Otto 2012).

Die verband tussen die opeenvolgende organisasies word nie net in die deurlopende teologiese diskoers sigbaar nie, maar ook in en deur dieselfde persone wat betrokke was by die klag teen Geyser, die Eietydse Getuienis, steedsHervormers en ontstaan van die Geloofsbond van Hervormde Gemeentes.

\section{Besluit oor apartheid AKV 2001}

In ons lengtesnit moet ons ook kennis neem van die 66e AKV van 2001, toe die saak van 'n skuldbelydenis oor apartheid op die tafel was. Drie memoranda is aangebied, en sonder bespreking is die dokument van dr. D.J.C. van Wyk (sr.), as 'n kompromis, aanvaar. In die skuldbelydenis oor apartheid stel die AKV:

dat die kerk kennis neem van die misdade wat onder die apartheidsbeleid gepleeg is, selfs deur lidmate van die kerk. Daarvoor bely die kerk sy skuld voor God en word die lidmate opgeroep tot ' $n$ skuldbelydenis teenoor God en medemens. (Nederduitsch Hervormde Kerk van Afrika [NHKA] 2001:171-174)

Die opvallende van hierdie besluit is dat apartheid per se nie veroordeel word nie, maar wel die misdade wat mense gepleeg het om apartheid in stand te hou. Die skuldbelydenis verwoord ook nie iets van die Hervormde Kerk se teologiese begronding en goedkeuring van apartheid nie. Die skuldbelydenis fokus op die individu, nie op die kerk nie en ook nie op apartheid as politieke bestel nie.

Tog was hierdie uitspraak van die AKV ingrypend anders as die kerk se regverdiging van apartheid, soos verwoord oor etlike dekades in amptelike dokumente van die kerk (vgl. Dreyer 2013a). Baie het die mening gehuldig dat die 2001 uitspraak oor apartheid voldoende sou wees met die oog op die herstel van die Hervormde Kerk se lidmaatskap van die World Alliance of Reformed Churches (WARC), nou die World Communion of Reformed Churches (WCRC).

\section{Nasionale Colloquium (2006)}

Die Nasionale Colloquium (27-29 April 2006) het die Hervormde Kerk met die vraag na die 'Identiteit en relevansie van die Hervormde Kerk in die 21e eeu' gekonfronteer. Charmaine Lines (2006:20-21), destyds kommunikasiebestuurder van die Hervormde Kerk, het in 'n artikel met die titel 'God se Gees was daar', dit duidelik gestel dat 'die Colloquium die begin van ' $n$ proses is waar lidmate van die Hervormde Kerk met mekaar kon gesels oor wie en wat ons kerk is en behoort te wees.'

In die aanloop na die Colloquium is predikante, ringskommissies, ampsdraers en lidmate uitgenooi om aan die gesprek deel te neem. Ongeveer 150 lidmate en ampsdraers het die geleentheid buite Pretoria bygewoon.

Die uitkoms van die Nasionale Colloquium is verwoord in 'n Herderlike Skrywe van die Kommissie van die AKV wat in 
September 2007 na al die gemeentes gestuur is, onder die titel 'Identiteit en relevansie van die kerk in die 21e eeu' (NHKA 2007). Die Herderlike Skrywe begin met die woorde:

Die Kommissie van die Algemene Kerkvergadering is van oortuiging dat die krisis van die tyd nie bepalend vir die wese van die kerk kan wees nie. Die wese van die kerk word bepaal deur die Drie-enige God en die evangelie van Jesus Christus. (bl. 1)

Die Kommissie van die AKV en by name prof. J. Buitendag as voorsitter, het onder skerp kritiek deurgeloop vir die 'vreemde' Colloquium en Herderlike Skrywe, wat deur sommige beskryf is as 'breinspoeling'.

Wat mense waarskynlik vergeet het, is dat die Hervormde gesprek oor kerkwees reeds 'n dekade tevore begin het. In 1995 is die Predikantevergadering en 'n hele uitgawe van HTS Teologiese Studies/Theological Studies (HTS 51[3]) aan ekklesiologie en kerkbegrip gewy. In hierdie uitgawe, waaraan al die teoloë van die kerk meegewerk het, het daar reeds uiteenlopende denke oor kerkwees na vore gekom (vgl. Dreyer 2011a).

Die Kommissie van die AKV wat in 2001 verkies is, het onder leiding van prof. T.F.J. Dreyer die gesprek oor kerkwees voortgesit. Dit het sigbaar geword in twee sake, te wete die visie 'Jesus Christus die enigste hoop vir die wêreld' asook die 'Basiskursus in Bedieningspraktyk', wat nuwe kontoere getrek het vir die bedieningspraktyk in die Hervormde Kerk.

Dit is opmerklik dat die gesprek oor kerkwees sedert 2001 onverpoosd voortduur. Tydens Voortgesette Teologiese Toerusting (VTT), die opening van die Hervormde Teologiese Kollege (HTK), Inligting- en Besprekingsvergaderings en Ringsvergaderings was kerkbegrip en kerkwees dikwels op die agenda (vgl. Dreyer 2011b, 2011d, 2013b).

Ook die 70e AKV wat van 22-27 September 2013 sitting geneem het, het die eerste twee dae aandag gegee aan 'n verskeidenheid vrae wat verband hou met kerkwees in die toekoms.

Die Hervormde Kerk se gesprek oor kerkwees en kerkbegrip van die laaste 20 jaar, vertoon groot diversiteit. Die tipiese presbiteriaal-sinodale en volkskerklike kerkbegrip wat aan die Hervormde Kerk 'n sterk institusionele karakter verleen (vgl. Dreyer 2011e:65-74), het stelselmatig begin plek maak vir 'n organiese kerkbegrip waar die klem geplaas word op die kerk as die liggaam van Christus. Hierdie ekklesiologiese verskuiwing het heelwat kritiek uitgelok, veral ten opsigte van die $69 \mathrm{e}$ AKV se besluite oor volkskerk en missionale kerkwees (NHKA 2010:60, 83-84).

\section{Besoek van World Alliance of Reformed Churches (2006)}

Die proses om die Hervormde Kerk se lidmaatskap van die WARC te herstel, het tydens die 67e AKV (2004) momentum gekry. Dit was tegelyk die begin van skerp meningsverskil in die kerk (vgl. Dreyer 2011c). Dit het daartoe gelei dat 'n afvaardiging van die WARC die Hervormde Kerk in 2006 besoek het.

Die afvaardiging het bestaan uit dr. Setri Nyomi (Algemene Sekretaris), ds. Peggy Kabonde (Zambië), ds. Sandy Horsburgh (Skotland), dr. Felix Chingota (Malawi), dr. Egbert Rooze (België), prof. Thias Kgatla (Suid-Afrika) en dr. Kobus Gerber (Suid-Afrika).

Die WARC het die Hervormde Kerk van 05-08 Junie 2006 besoek. Samesprekings is met die Moderamen, Kommissie van die Hervormde Kerk, en die Raad vir Ekumene en Hervormde Dosentevergadering gevoer. Daar is ook met die Moderamen van die Hervormde Kerk in Suidelike Afrika (MRCC) gesprek gevoer. Die doel van die besoek was om 'n verslag aan die WARC se Uitvoerende Komitee te lewer, waarin aangedui word tot watter mate die Hervormde Kerk voldoen aan die voorwaardes vir hertoelating tot die WARC. Hierdie voorwaardes is die volgende:

- Swart Christene word nie van eredienste en deelname aan die nagmaal uitgesluit nie.

- Konkrete ondersteuning word in woord en daad gebied aan diegene wat gely het onder apartheid.

- Ondubbelsinnige sinodale besluite word geneem wat die teologiese begronding van apartheid verwerp.

Tydens die onderhandelinge is ooreengekom dat die Hervormde Kerk reeds voldoen aan die eerste twee vereistes maar, strydig met die verwagting van die Kommissie van die AKV, was die WARC afvaardiging teleurgesteld oor die besluit wat die 66e AKV oor apartheid geneem het. Dit hou verband daarmee dat die AKV hom nie oor apartheid as sodanig of oor die teologiese regverdiging daarvan uitgespreek het nie, maar slegs oor misdade wat deur individue gepleeg is.

Die WARC afvaardiging was ook baie krities oor die Ordereël IV in die Kerkorde, wat hulle beskou het as 'n verskuilde voortsetting van Artikel III wat lidmaatskap van die kerk tot blankes beperk het. Die WARC afvaardiging het wel positief gereageer oor die uitkoms van die Nasionale Colloquium, veral ten opsigte van die standpunt dat die verhouding met die MRCC moes verbeter.

Die gevolgtrekking waartoe die WARC afvaardiging gekom het, was dat die 2001 besluit oor apartheid nie voldoen aan die vereistes van die 1982 Ottawa Resolusie nie, wat vereis dat die AKV die teologiese regverdiging van apartheid onvoorwaardelike moet herroep (vgl. WARC 2006).

Daar was besonder skerp reaksie vanuit die geledere van die HCM Fourie Stigting teen die WARC, die Kommissie van die AKV se hantering van die saak asook individuele lede van die Kommissie. Dit is duidelik dat die gebeure rondom die Colloquium en die besoek van WARC 'n diep en ernstige vertrouensbreuk tussen die Kommissie van die AKV en 'n sekere deel van die Hervormde Kerk lidmate veroorsaak het. 
Die vertrouensbreuk word breedvoerig deur A.D. Pont (2013b), in sy reaksie op Besluit 54, verwoord. Daarin verwys hy onder andere na die gebeure van 2006:

Daar is op gewys dat die Kommissie van die AKV al in 2006 besluit het om 'n nuwe koers in te slaan. Die pad wat die Hervormde Kerk geloop het vanaf 1852, het die Kommissie in 2006 by ' $n$ waterskeiding gebring. Die destydse voorsitter van die Kommissie het glo 'disdain' ervaar toe hy sy voorgangers se menings en optrede nagelees het. Daar is toe gekies om ' $n$ nuwe pad te gaan en dit was toe glo om aansluiting te soek by die Engelstalige WARC/WCRC. Daarom kan die Teologiese Fakulteit aan UP seker maar verengels en is ook die vak Kerkgeskiedenis afgeskaf sodat die gewetes nie meer belas sal word deur die 'besoedelde verlede' van die Hervormde Kerk nie.

Maar nou is daar ook gemeentes en diensknegte van die Heer van die Kerk wat ook by die waterskeiding uitgekom het en besluit het dat die prys wat gevra word deur die meerderheid van die AKV'n bietjie te hoog is. Daarom is dit nogal vreemd dat daar so geswets en gedreig word deur die meerderheidsgroep in die Hervormde Kerk omdat daar gelowiges, diensknegte van Jesus Christus en gemeentes is wat tevrede is om te bly wat hulle nog altyd was en nog steeds is: Hervormers wat bly by die onveranderde Formuliere van Eenheid en met dankbaarheid die Bybel lees wat hulle, volgens die Nerlandse Geloofbelydenis (NGB), verstaan as die Woord van God.

Pont (2013b) is verder van mening dat die AKV se besluite oor apartheid berus op (1) 'n afwykende leer en (2) bevrydingsteologie. Hy is ook van mening dat die verskillende denkrigtings in die Hervormde Kerk so wesenlik verskil, dat dit uitsluitend is. Wie Besluit 54 aanvaar, kan volgens hom nie meer deel van die ware kerk wees nie. Dit is ook duidelik dat hy die mening huldig dat die Geloofsbond die ware voortsetting van die Hervormde Kerk is. Gemeentes en lidmate wat Besluit 54 steun, het die geloofsband met die 'ware' Hervormde Kerk verbreek.

\section{Besluite van die 69e Algemene Kerkvergadering (2010)}

Die 68e AKV (2007) wou geen finale besluit oor die WARC of apartheid neem nie. Talle gemeentes het beskrywingspunte ingedien wat beswaar maak teen die aanbevelings van die WARC afvaardiging.

Tydens die 69e AKV (2010) het die saak weer aan die orde gekom. Dit was die gevolg van bepaalde gebeure, wat ook kortliks genoem moet word. Vyf predikante van die Hervormde Kerk (proff. J. Buitendag, E. van Eck, J.A. Loader, A.G. van Aarde en Y. Dreyer) het 'n openbare verklaring uitgereik waarin hulle die teologiese regverdiging van apartheid verwerp. Die dosente is aangekla deur lede van Die Verbond/HCM Fourie Vriendekring as sou hulle die goeie orde in die kerk versteur, kerkskeuring bevorder en hulle nie onderwerp aan besluite van die (1982) AKV nie (Van der Merwe 2012:1).

Die saak het voor die Kommissie van die AKV gedien, waarna al die partye ooreengekom het dat die standpunt van die dosente (wat bekend geword het as as Besluit 54) aan die AKV voorgelê sou word vir beoordeling. In die Agenda van die 69e AKV staan dit as 'n beskrywingspunt van die dosente, wat foutief is. Beskrywingspunt 54 is deur die Kommissie van die AKV op die agenda geplaas as deel van die proses om die konflik te beredder.

Tydens die 69e AKV het 247 (58.8\%) predikante en ouderlinge tot die gevolgtrekking gekom dat die Hervormde Kerk se teologiese regverdiging van apartheid in die verlede, strydig met die evangelie was (NHKA 2010). Besluit 54 van die 69e AKV het soos volg gelui:

Die 69e AKV maak in die lig van die 68e AKV se besluit dat dit verkeerd was om ' $n$ bepaalde regeringsbeleid (apartheid) goed te praat, onomwonde die uitspraak dat apartheid nie teologies geregverdig kan word nie. Die kerk verwerp sy goedkeuring van apartheid omdat dit:

- in stryd is met die evangelie van Jesus Christus

- gebaseer is op die idee van onderlinge onversoenlikheid

- onreg sanksioneer

- die beeld van God in mense aantas.

Die vergadering beklemtoon die Bybels-teologiese aard van die uitspraak. (bl. 343-344)

Die 69e AKV het ook met ' $n$ meerderheidstem besluit dat Ordereël 4 van die Kerkorde (NHKA 1997:69) gewysig moet word met die weglating van die begrip 'volkskerk', om moontlik soos volg te lees: 'Die Hervormde Kerk, as deel van die een, algemene, apostoliese kerk is geroep tot die verkondiging van die evangelie van Jesus Christus aan alle mense.' Die saak is verwys na die komitee wat besig is om die Kerkorde te herskryf (vgl. Beskrywingspunt 32 en die daaropvolgende Besluit en Amendement van die 69e Algemene Kerkvergadering soos verwoord in die Besluitebundel [NHKA 2010:60]).

'n Derde groep besluite wat die AKV geneem het, het te doen met die ontwikkeling van missionale kerkwees en die herskryf van die Kerkorde op grond van 'n missionale ekklesiologie. Ook hierdie besluit, hoewel dit sonder veel bespreking deur die AKV aanvaar is, het later heelwat kritiek uitgelok omdat dit strydig is met die tradisionele volkskerklike apostolaat van die Hervormde Kerk.

Tydens die vergadering het talle afgevaardigdes hulle teenstem laat aanteken en selfs die vergadering verlaat. Hierdie drie sake, te wete Besluit 54, Ordereël IV (volkskerk) en missionale kerkwees is deurlopend gekritiseer vanuit die kringe van die steedsHervormers, as synde die resultaat van 'n vreemde leer en teologie.

\section{Buitengewone Algemene Kerkvergadering}

Op 04 en 05 Oktober 2011 het die Algemene Kerkvergadering vir 'n buitengewone sitting gekonstitueer. Die Kommissie van die AKV het die buitengewone AKV byeengeroep om aandag te gee aan 'n Beswaarskrif wat by die Kommissie van die AKV ingehandig is. Die Beswaarskrif is ingehandig op grond van Ordinansie 1.2.1. van die Kerkorde (NHKA 
2010:3). Dit lees soos volg: 'Besware teen leerbeslissings van die Algemene Kerkvergadering word aan die Kommissie van die Algemene Kerkvergadering voorgelê.'

Die Komitee van die steedsHervormers het op 30 November 2010 met die Moderamen in gesprek getree nadat hulle opgeroep is vir gesprek. Hierdie vergadering is deur bykans al die kommissielede bygewoon. By dié geleentheid is die Beswaarskrif deur die beswaarde lidmate en ampsdraers op die tafel geplaas, maar dit is nie bespreek nie. Op 28 Januarie 2011 het die Kommissie 'n buitengewone vergadering belê waar verdere aandag aan die Beswaarskrif en die proses wat gevolg behoort te word, gegee is. Die Kommissie het na hierdie vergadering 'n Herderlike Skrywe aan al die gemeentes van die Hervormde Kerk gestuur om hulle van die beswaar in te lig en hoe die Kommissie die saak verder gaan hanteer.

Die Kommissie was ook bereid om verteenwoordigers van die beswaarde lidmate op 18 Februarie 2011 te woord te staan oor die proses, maar hulle het aangedui dat hulle so 'n gesprek nie nodig ag nie. Die Kommissie het daarna, soos die Kerkorde daarvoor voorsiening maak, die advies van verskeie deskundiges oor die saak ingewin en oorweeg. Die meerderheid van die deskundiges het nie saamgestem met die wese van die beswaardes se argumente nie, maar almal was dit eens dat hierdie belangrike teologiese aangeleenthede is wat verdere debat vereis.

Die Kommissie het die Beswaarskrif tydens 'n werkwinkel op 04 en 05 Maart 2011 volledig behandel. Daarna is die Beswaarskrif weereens in debat geneem op 10 en 11 Maart 2011 tydens die Kommissie se geskeduleerde vergadering. Daar is by hierdie geleentheid weer met die komitee van die beswaardes gesprek gevoer.

In die oorweging van die saak was dit ' $n$ vraag of Besluit 54 inderdaad 'n leerbeslissing behels. Omdat Ordereël 1.1.4. (NHKA 2010:1) stipuleer dat die leer van die kerk ook tot uitdrukking kom in teologiese uitsprake, het die Kommissie geoordeel dat die Beswaarskrif wel by 'n AKV kan dien. $\mathrm{Na}$ verdere konsultasie met verskillende rolspelers en korrespondensie met die beswaarde lidmate en ampsdraers, is besluit om die Beswaarskrif tydens ' $n$ buitengewone AKV ter tafel te neem, sodat die Kerk weer die geleentheid kry om daaroor te besin en besluite te neem.

Die Kommissie het verskeie teoloë versoek om kommentaar te lewer op die Beswaarskrif. Die teologiese refleksie en kommentaar is volledig in die Agenda van die buitengewone AKV opgeneem en kan daar nagelees word. Een van die kern besware was teen die uitdrukking 'beeld van God in die mens'. Die Beswaarskrif het groot gewag daarvan gemaak dat die uitdrukking ' $n$ afwykende antropologie en versaking van die reformatoriese leer verteenwoordig.

Miskien kan met een kritiese opmerking teenoor die standpunt van die Beswaarskrif volstaan word, 'n saak waarop prof. J.A. Loader die vergadering attent gemaak het: Calvyn ([1559] 1949) skryf in sy Institusie (III/7/6) soos volg:

Alleen op hierdie manier bereik ons wat nie alleen moeilik is nie, maar heeltemal teen ons natuur, naamlik om diegene lief te hê wat ons haat, goed te doen vir kwaad en te seën vir vloek, deurdat ons onthou dat ons nie moet let op die boosheid van mense nie, maar moet kyk na die beeld van God in hulle,'n beeld wat hulle foute bedek en uitroei deurdat die skoonheid en waardigheid daarvan ons trek om hulle lief te hê en te omhels. (bl. 191)

Die Beswaarskrif teen Besluit 54 van die 69e AKV (NHKA 2011) begin deur te wys daarop dat Besluit 54 'verteenwoordig 'n leerverandering in ons Kerk en is nie op waarheid en feite gebaseer nie.' Die Beswaarskrif het van die standpunt uitgegaan dat Besluit 54 historiese wanvoorstelling, prosedurefoute sowel as leerstellige probleme bevat:

Leer:

- Besluit 54 verteenwoordig vreemde leer aangesien dit stel dat 'die beeld van God in die mens is.'

- Besluit 54 berus op Bevrydingsteologie omdat dit die 1982 status confessionis van WARC napraat. Die besluit is beïnvloed deur 'n 'ekumenistiese ideologie'.

Historiese wanvoorstelling:

- Besluit 54 gee 'n wanvoorstelling van apartheid. Apartheid kan in werklikheid nie veroordeel word nie. Die Beswaarskrif stel dit soos volg:

Die derde begrondende stelling stel dat apartheid onreg sanksioneer. Die status confessionis van die WARC verduidelik hierdie onreg as sou die maatreëls van afsonderlike ontwikkeling bedoel gewees het om blankes ten koste van swartes te bevoordeel. Hierdie stelling is nie waar nie. Hierdie stelling neem geensins die geskiedkundige gebeurtenisse, ooreenkomste, konvensies en politieke bepalings in ag nie. (NHKA 2011:38-44)

Prosedure foute:

- Besluit 54 verwys na 'n besluit van die 68 e AKV, wat nie 'n besluit was nie maar slegs 'n aanbeveling. Dit kom neer op 'n leuen.

- Daar het nie genoeg memoranda oor die saak in die kerk gesirkuleer nie.

- Die besluit is ultra vires omdat daar verwarring was oor die bedoeling van Besluit 54 .

Die buitengewone Algemene Kerkvergadering (NHKA 2011:84-85) moes gevolglik oor die volgende sake uitspraak lewer:

- Was Besluit 54 'n skuldbelydenis of 'n teologiese uitspraak? Stemming: 308 (66\%) stem dat dit 'n teologiese uitspraak was.

- Was Besluit 54 'n leerbeslissing? Stemming: 327(69\%) stem 'nee'.

- Was Besluit 54 in 'n verandering aan die Belydenisskrifte? Stemming: 360 (75\%) 'nee'. 
- Was Besluit 54 'n nuwe belydenis? Stemming: 370 (78\%) 'nee'.

- Was Besluit 54 ultra vires? Stemming: 315 (67\%) 'nee'.

Die AKV het met 'n groot meerderheid die argumente van die Beswaarskrif verwerp. As kompromis is 'n nuwe besluit deur T.F.J. Dreyer, ondersteun deur al die vorige voorsitters van die $\mathrm{AKV}$, geformuleer wat die besware in die Beswaarskrif moes aanspreek. Daar is met 256 teen 192 stemme (57\%) die volgende besluit geneem:

Die Nederduitsch Hervormde Kerk van Afrika verklaar dat die politieke beleid van apartheid wat toegepas is in die Republiek van Suid-Afrika, nie teologies geregverdig kan word nie, en herroep hiermee alle goedkeuring in die verlede van die beleid in uitsprake deur die Kerk en namens die Kerk. Dit was in stryd met die evangelie van Jesus Christus. (NHKA 2011:85)

Daar is ook twee ander belangrike besluite geneem: (1) Die Hervormde Kerk wil nie modaliteite in sy midde toelaat nie en (2) die Kommissie van die AKV moet 'n komitee aanwys om gesprek met beswaarde lidmate te voer, in 'n poging om groter begrip en verdraagsaamheid te bevorder. Die komitee is benoem onder leiding van dr. Kobus Labuschagne, maar kon ongelukkig nie daarin slaag om die konflik te besweer nie.

\section{Staat van Belydenis}

Op 02 Junie 2012 het die steedsHervormers 'n Staat van Belydenis teen die Hervormde Kerk verklaar. In die nagaan van die dokumentasie rondom die Staat van Belydenis, het dit duidelik geword dat daar verskillende tekste is - party langer en party korter. Die korter weergawe wat die mees bekende is lui soos volg:

So glo ons - ons kan nie anders nie

Ons onwrikbare geloof in God Drie-enig, ons vashou aan die Bybel as ons enigste kanon, ons aanvaarding van die Belydenisskrifte, die Proponentsformule, dring ons daartoe om te staan by ons geloofsoortuigings. Ons smeekbede is: Help ons, God.

Indien alle vorme van protes nie suksesvol was nie, is dit nodig om te bely: Ek distansieer myself en sonder myself af teen hierdie vreemde konsep en verstaan dit as ' $n$ vreemde leer. Hierdie belydenis spreek elke lidmaat individueel aan. Elkeen moet self kies: Waar staan ek? Dit is ons oortuiging dat ons nou by hierdie punt in die geskiedenis van die NHKA gekom het.

In al hierdie sake wat die eer van God, die verlossing van die mens en die beloftes van die ewige lewe aanraak en ten opsigte waarvan ons verplig is om die Here God te gehoorsaam, kan ons geen toegewing aan die (georganiseerde) meerderheid maak nie. Buitendien moet in sake waar dit gaan om die eer van God, ons verlossing uit die sonde en die ewige lewe, elke gelowige opstaan en homself voor God verantwoord en niemand kan hierin agter ' $n$ ander een wegkruip nie.

Saak 1

Die mens is beelddraer van God ten opsigte van 'n verhouding met God, 'n opdrag van God en verantwoordelikheid teenoor God. Die BAKV se besluit dat daar geen vreemde leer teenwoordig is in 54/69, is nie korrek nie. Die beeld van God is nie in die mens nie. Ons bely die Godheid van Christus en ook sy menswording; sy twee nature (ware mens, ware God); sy maagdelike geboorte; sy plaasvervangende en versoenende dood aan die kruis. In Christus is God, nie in die mens nie.

Ons verklaar daarom dat ons in ' $n$ Staat van Belydenis is en dat die AKV 'n vreemde teologiese konsep as waarheid aanvaar het deur te stem dat die beeld van God in die mens is. Ons roep lidmate en ampsdraers van die NHKA daartoe op om te erken dat die mens volkome sondaar is en dat ons redding buite onsself in Jesus Christus is.

Saak 2

Die BAKV se besluit om 54/69 te behou, verloën die evangelie van Jesus Christus as die opgestane HERE. Die NHKA het nog altyd vasgehou aan die evangelie van Jesus Christus wat ons verlos het uit die mag van sonde en dood. Sedert 54/69 stel die Kerk dat daar geen ander evangelie is as 'die evangelie van die deernis van God' nie.

Ons verklaar daarom dat ons in ' $n$ Staat van Belydenis is en dat die AKV' $n$ teologie verkondig wat nie in lyn is met die Bybel en die belydenisskrifte nie. Ons roep die AKV daartoe op om terug te keer tot die belydenis dat Jesus ons red van sonde en dood.

Saak 3

Die sake wat nou as die kern van die Kerk aangedui word,maak van die NHKA ' $n$ organisasie van diensbaarheid. Hierdie organisasie se doelwitte is dan gemik op sosiale verandering en nie meer op evangelieverkondiging nie. Dit lyk asof die kerk 'n oppervlakkige teologie aanhang wat gryp na bemarkingstruuks om die Kerk te laat 'oorleef en relevant te wees.'

Ons verklaar daarom dat ons glo die AKV slaan 'n teologiese rigting in waar die heil van die mensdom gesoek word, nie in God nie, maar in die huidige sogenaamde sosiale geregtigheid. Ons roep die AKV daartoe op om weer die vooruitsig van 'n wederkoms en die volle rykdom van God se verlossende genade raak te sien.

Saak 4

Die sewende gebod, asook die hele Bybel (vgl. Sondag 41 van die Heidelbergse Kategismus) verstaan die verhouding tussen een man en een vrou as die ideale verhouding binne die wil van God. Die Bybel veroordeel homoseksuele verhoudings.

Ons verklaar daarom dat ons in 'n Staat van Belydenis is omdat die AKV'n teologie aanhang wat nie erns maak met die Bybel as die Woord van God nie. Ons roep die AKV daartoe op om terug te keer tot ' $n$ verstaan van die Tien Gebooie wat in lyn is met die Bybel en die Belydenisskrifte.

Saak 5

Die benadering deur dosente en die predikante van die AKV wat gestem het ten gunste van 'n interpretasie van die Belydenisskrifte, weerspreek die Proponentsformule en Ordinansie 1.1.2. Die gedagte dat die geloofsbelydenisse en die belydenisskrifte eietyds geïnterpreteer moet word, ontken die waarheidskarakter daarvan en is meer in lyn met die vrysinnigheid.

Ons roep die ampsdraers van die NHKA daartoe om te erken dat ons die belydenisskrifte onderteken juis omdat hierdie geskrifte in ooreenstemming is met die Woord van God.

Saak 6

Binne veral die Teologiese Opleiding het dit mode geword om die sogenaamde Q-bron en die Thomas-evangelie aan te haal. Hierdie benadering is slegs moontlik indien die gesag van die Bybel nie aanvaar word nie en na teologiese antwoorde 
gesoek word buite die Bybel om. Op grond van die Bybel bely ons die Godheid van Christus en ook sy menswording; sy twee nature (ware mens, ware God); sy maagdelike geboorte; sy plaasvervangende en versoenende dood aan die kruis; sy liggaamlike opstanding en sy hemelvaart.

Ons roep die AKV daartoe op om die Bybel as Woord van God te aanvaar en as die enigste gesagvolle bron vir prediking en norm vir teologiese navorsing vir die Kerk te erken. Ons verklaar dat die Kerk in sy goedkeuring en aanvaarding van akademiese navorsingsresultate en skrywes in amptelike publikasies van die Kerk wat die teendeel wil verkondig, 'n godslasterlike leer akkommodeer en selfs beloon. Ons roep lidmate en ampsdraers van die NHKA daartoe op om te erken dat Jesus Christus waarlik God en mens is, uit ' $n$ maagd gebore is, aan die kruis gesterf het, uit die dood opgestaan en na die hemel opgevaar het soos die Woord duidelik verkondig.

\section{Saak 7}

Eksodus 20:16 'Jy mag nie vals getuienis teen 'n ander gee nie'. Die negende gebod vereis van ons om in alle gevalle die waarheid te koester en die leuen te verwerp, ongeag omstandighede en die prys wat betaal moet word. Indien die Kerk die negende gebod oortree, het die Kerk homself begin sien as 'n grootheid wat uitstyg bokant God en God se gebod.

Ons verklaar daarom dat ons in ' $n$ Staat van Belydenis is en dat die AKV die oortreding van die negende gebod goedkeur en so die kern van die evangelie aantas. Die Kerk moet erken dat die 68e AKV geen besluit oor politieke beleid geneem het nie. Die AKV moet beide die aanvaarding van beskrywingspunt 54 van die 69e AKV, asook die opvolg besluit van die BAKV, onvoorwaardelik herroep. (steedsHervormers 2012e)

Hierdie Staat van Belydenis is tydens die onlangse vergadering van die Geloofsbond van Hervormde Gemeentes bekragtig. Dit verwoord die leergeskil tussen die Geloofsbond en die NHKA en vorm tegnies die basis waarop die onafhanklike gemeentes hulle van die NHKA distansieer.

\section{Die rol van die media}

Ek meen dat dit van uiterste belang is dat ons sal kennis neem van die rol wat die openbare, kerklike maar veral die sosiale media in onlangse gebeure gespeel het. Vir die eerste keer in die geskiedenis van die Hervormde Kerk, is sosiale media aangewend om die kerk in ' $n$ bepaalde rigting te laat beweeg.

Lidmate wat beswaard was het briewe aan die pers gerig, 'n webblad is gevestig ${ }^{1}$ en sosiale media is bykans daagliks benut om standpunte te stel en besluite van die kerk te kritiseer. ${ }^{2}$ Al die korrespondensie, artikels, koerante, video's en tydskrifte was vir lidmate deur die internet beskikbaar. Deur 'n knoppie op die rekenaar te druk, kon enigeen 'n standpunt stel, kritiek uitspreek of daarvan kennis neem.

'n Enkele voorbeeld (ter illustrasie) vind ons in Koers van Desember 2012 onder die opskrif 'Red die Hervormde Kerk se karakter':

Die besluit van die Algemene Kerkvergadering in 2010 en 2011 voer die Sosialistiese Teologie teenoor die Bybelse Teologie in

1.http://www.steedshervormers.co.za/

2.https://www.facebook.com/pages/Steedshervormers/118368828245168 ons Kerk in. Met die dwaling dat elke mens in hom/haar iets Goddelik het, sleep die wêreldekumene ons nou ook in om ons afsonderlike bestaan as volk as teen die evangelie te verwerp. Met die besluit dat al ons Kerk se besluite voorheen oor apartheid teen die evangelie was! (Kotzé 2012)

Die Kommissie van die AKV is in die openbare en kerklike media, briewe, Facebook en hofaansoeke verwyt en beskuldig van 'n geheime agenda, bedrieglike optrede, viktimisasie en onkerkordelike optrede. 'n Enkele voorbeeld (waarvan daar letterlik tientalle bestaan) sal die punt illustreer. Dr. Johan Otto skryf in reaksie op Omsendskrywe 17/2012 op die webblad van steedsHervormers (2012d) die volgende: 'Dit is nou tyd dat die eiegeregtige en aanmatigende magsvergryp van die KommAKV ontmasker word.' Hy kritiseer die omsendskrywe punt vir punt en verwerp dit in baie skerp bewoording. Die kommentaar was vir alle lidmate beskikbaar om te lees.

Ook op ander webtuistes het die saak besonder baie aandag getrek. Hier word slegs twee voorbeelde genoem ter illustrasie. Op die webblad van die Noordoos-Transvaalse Boerekommando, 'n verregse organisasie, lewer die webblad redakteur Manie (2012) kommentaar op Neels Jackson se berig in Beeld dat Gemeente Meyerspark hulleself onafhanklik verklaar het van die Hervormde Kerk. Hy plaas sy kommentaar onder die opskrif 'Leraar of Leuenaar?' en skryf dan:

Baie mense weet nie hoe 'n klomp Godloënaars van die sinodes en predikante is nie. Ek is in besit van ' $n$ video wat skelm geneem is in die sinode vergaderings en dit is skokkend om te hoor wat daar bespreek word. Onder andere dat die Seun van God nie opgestaan het en opgevaar het na die hemel nie, 'maar dat hy deur die honde opgevreet is', en dat dit net ' $n$ miete in die mens se kop is dat hy opgevaar het, dit is hoekom hulle hom nie by sy graf kon vind nie! So is daar ook nog 'n paar ander stellings wat gemaak is. Maar nee, hoekom sal Dominee (demoon) nou lieg? ... Hoeveel van hulle is Vrymesselaars, selfs by die teologiese skool pryk die Vrymesselaars tekens volop daar en besoek hulle ook die hole van die Vrymesselaars. Ek sal binnekort die video op die web plaas. Ek dink die tyd dat ons as Volk 'n verootmoedigings dag moet uitroep is 'n noodsaaklikheid, landswyd!

Reeds in 2009, in die aanloop tot die 69e Algemene Kerkvergadering, lewer dr. S.H. Gregan (voormalige ouderlingslid van die Kommissie van die AKV) kommentaar op gebeure in die Hervormde Kerk onder die opskrif 'Nog 'n Afrikaner-bastion val'. Op die webblad van die Afrikaner Volksparty skryf hy oor liturgiese vernuwing, 'n gesamentlike verklaring tussen die NG Kerk en Hervormde Kerk, die WARC en kom dan tot die gevolgtrekking:

Dit was 'n eer om as 'Hervormer' bekend te kon staan. Dit is egter net 'n dwaas wat sal vasklou aan 'n naam en vergange se herinneringe. Ook die naam sal op aandrang van die vyand uiteindelik moet verdwyn omdat ook dit 'aanstoot' gee. Soos die Nasionale Party in 1969 en weer in 2008 herstig moes word, so sal die dag aanbreek dat Christen-nasionaliste weer ' $n$ nuwe (Hervormde) kerk sal stig. Daardie dag kom vinnig nader. Dit is immers ons, wat in 'n eie afsonderlike Godgegewe identiteit van ons volk glo, se taak en ons roeping. Hierdie nuwe kerk sal 
nie verskoning vra vir apartheid nie. En hierdie lidmate sal weet dat diskriminasie, ja die voorkeur vir die eie, 'n lewenswet is waarsonder geen volk ' $n$ identiteit kan hê en homself kan betuig nie. Ja, waarsonder geen volk kan voortbestaan nie. (Gregan 2009:1)

Ook skriftelike kommunikasie deur middel van briewe en e-pos getuig van 'n totale vertrouensbreuk wat plaasgevind het. Op 13 Augustus 2012 ontvang die Kommissie van die AKV die volgende brief van die Hervormde Kerkvereniging, waarin die volgende stelling gemaak word:

Maar dit is blykbaar niks vreemd vir die Kommissie om openlik te lieg nie, soos maar weer uit die skrywe van 3 Augustus blyk. Hoe moet die res van die Kerk opkyk na die leiers van die Kerk as hulle so openlik die waarheid verdraai en so onchristelik optree? A nee a - julle noem julleself dan predikante. (NHKA 2012a:9)

Die Kommissie van die AKV se kommunikasie met die kerk en steedsHervormers is dikwels gekritiseer, ook uit eie geledere. Dit was óf te min, óf te veel, óf te hardvogtig óf te sagmoedig. Die Kommissie is verkwalik omdat daar te laat en te stadig gekommunikeer is. Die interne spanning in die Kommissie het duidelike kommunikasie bemoeilik en selfs gelei tot uiteenlopende standpunte wat deur verskillende lede van die Kommissie gestel is. Die uiteenlopende standpunte het uiteindelik daartoe gelei dat dr. J.M.G. Storm (skriba) en oudl. J. Oberholzer uit die Kommissie bedank het.

Die Kommissie het van amptelike kommunikasiekanale gebruik gemaak om bepaalde standpunte te stel, te wete die kerklike tydskrifte, omsendskrywes en herderlike skrywes. Die Kommissie het ook toestemming verleen dat'n amptelike Facebookblad vir die kerk gevestig word. ${ }^{3}$

Daarbenewens het lede van die Kommissie sedert 2010 meer as 150 keer formeel of informeel met lidmate, ampsdraers, predikante, vergaderings van die ampte en byeenkomste gepoog om eensgesindheid te bevorder en inligting deur te gee (vgl. NHKA 2013:143-160). Die huidige Kommissie en Moderamen het in die 3-jaar termyn 48 keer vergader om aan die sake aandag te gee. Van die vergaderings moes op geheime plekke plaasvind, omdat sensitiewe inligting (bv. oor hofsake) uitgelek het en op Facebook verskyn het selfs nog voor die vergadering afgehandel was. Dit het die Kommissie genoodsaak om 'n Litigasie Komitee aan te wys met ' $n$ mandaat om sake te hanteer, met beperkte inligting aan die Kommissie van die AKV.

Die Kommissie het deurlopend gepoog om die Kerkorde te interpreteer en toe te pas. Daaroor was daar groot verskil van mening, onder andere oor die saak van lidmaatskap. Die Kommissie was van meet af oortuig daarvan dat bepaalde optrede van die steedsHervormers hulle lidmaatskap van die Hervormde Kerk de iure en de facto ophef.

Dit is ook opvallend hoe dikwels kommunikasie in die sosiale media getuig van foutiewe inligting, uiteenlopende

3.https://www.facebook.com/groups/ $2756611001 /$ ?fref=ts interpretasies van gebeure en selfs moedswilligheid. Dit kan met enkele voorbeelde geillustreer word, soos die volgende oor ' $n$ 'nuwe teologiese rigting':

Op etiese vlak kom die nuwe teologiese rigting aan die orde in die manier waarop die huwelik in gedrang gebring word. Vele voorbeelde sou gestel kon word, maar die duidelikste voorbeeld is die beskerming wat die Hervormde dosente bied aan ' $n$ homoseksuele student. Op hulle aandrang is die student wat in 'n openlike intieme verhouding met ' $n$ man is, steeds student van die Kerk, studeer hy einde 2012 af en sal dan vroeg 2013 beroepbaar wees. Die dosente se etiek is ver verwyderd van dit wat 'n geslag gelede die oortuiging was. Daarmee saam het die fakulteit as oop ekumeniese instansie geen duidelike Hervormde inslag nie. (steedsHervormers 2012c)

Opvallend genoeg is die inligting nooit reggestel of vermeld dat die student op daardie stadium reeds van kursus verander het en nie beroepbaar gestel kón word nie, óf dat dit primêr die verantwoordelikheid van die Kuratorium is om sodanige besluite te neem nie.

\section{Van die Kommissie van die AKV word die volgende gesê:}

Op kerkleiding vlak was dit reeds onder die leiding van prof. Johan Buitendag duidelik dat 'n groep binne die Kerk 'n nuwe rigting ingeslaan het en die Kerk wou saamneem. Die selektiewe Colloquium was ' $n$ belangrike rigtingaanduider. Een van die sake aldaar was die beplande eenwording (struktureel) met die HKSA. Die Kerk was nie reg vir die vinnige verandering van rigting nie en die Buitendag Kommissie is uitgestem. Agter die skerms is daar steeds hard gewoeker en dit was veral ten opsigte van sake rondom ekumene waarop die meeste fokus geplaas is. (steedsHervormers 2012c)

Uit hierdie aanhaling is dit duidelik dat lidmate van inligting voorsien is wat beskou kan word as disinformasie. Strukturele eenwording tussen die Hervormde Kerk en die Hervormde Kerk in Suidelike-Afrika (HKSA), tans die Maranatha Reformed Church of Christ (MRCC) was en is nog nooit deur die Kommissie beplan nie, behalwe dat dit tydens die WARC besoek bespreek is sonder om dit verder te voer. Die 'Buitendag Kommissie' is ook nie uitgestem nie, maar was volgens die rotasiebeginsel, soos voorgeskryf in die Kerkorde, nie weer verkiesbaar nie.

Uit hierdie enkele voorbeelde is dit duidelik dat die onlangse gebeure in die Hervormde Kerk gekenmerk is deur 'n ongekende vlak van informasie en disinformasie, waardeur lidmate deurlopend blootgestel is aan opponerende en verwarrende standpunte. Hierdie nuwe vorme van kommunikasie het die kerklike speelveld onherroeplik verander. Kerklike gebeure, debat en besluitneming vind nie meer agter toe deure van vergaderings op grond van teologiese refleksie plaas nie, maar het deel geword van die openbare debat. Lidmate, selfs dié met min of geen begrip van teologiese vraagstukke, lewer uitsprake oor teologie as wetenskap. Drukgroepe, modaliteite en bewegings kan met relatief min moeite organiseer en uitsprake maak wat wyd kommunikeer. 
Die Hervormde Kerk sal nou en in die toekoms daarmee moet rekening hou dat elke debat 'n openbare debat sal wees. Die postmoderne tydsgees, waarin alle institusionele gesag óf bevraagteken óf geïgnoreer word, is 'n werklikheid waarmee die Hervormde Kerk rekening sal moet hou. Ek is ook van mening dat die gebruik van media ' $n$ beduidende rol gespeel het in die verdeeldheid wat toenemend sigbaar geword het.

\section{Die rol van organisasies}

Kort na die $69 \mathrm{e}$ AKV is daar begin om lidmate wat gekant was teen Besluit 54, bymekaar te bring en die verset teen Besluit 54 te koördineer. Die rol wat verskillende organisasies hierin gespeel het, mag nie onderskat word nie. Daar was veral drie organisasies wat 'n belangrike rol gespeel het in onlangse gebeure, te wete die HCM Fourie Vriendekring, die Hervormde Kerkvereniging en steedsHervormers. Daar kon nie inligting verkry word oor die JHWH Hervormde Studente Vereniging nie, aangesien die webblad geblokkeer word. Ek is wel bewus daarvan dat pogings aangewend is om teologiese studente op kampe te neem om hulle in te lig oor die afwykende tendense in die kerk.

Die ruimte ontbreek om op die geskiedenis en grondwet van elkeen van hierdie organisasies in te gaan. Dit kan aanvaar word dat bogenoemde organisasies instrumenteel daartoe was dat die kerklike afskeiding kon plaasvind. Regsgeleerdes het predikante en gemeentes van advies bedien oor moontlikhede hoe 'onafhanklikheid' bestuur kan word.

\section{Hoe het die proses verloop?}

Die sosiale media, advertensies in koerante, internet en Koers is benut om lidmate op te roep na byeenkomste waar verset teen Besluit 54 gekoördineer kon word. Die 'reëlingskomitee' rig die volgende uitnodiging aan lidmate in Koers van Desember 2012:

Gemeentes en lidmate kom op streeksbasis op 28 Januarie en 4 Februarie dwarsdeur die Kerk byeen om vas te stel wat ons te doen staan. Die Noord-Kaap kom byeen op Vryburg 10 vm 28 Januarie by die Hervormde Kerk. Dr. Malan Storm, gewese Skriba van die Algemene Kerkvergadering, sal DV ook teenwoordig wees. $U$ dringende teenwoordigheid kan verhinder dat $u$ vir die res van $\mathrm{u}$ lewe al ongelukkiger word oor die aftakeling van die karakter van ons volkskerk. Maak hierdie oproep wyd bekend in u gemeente. (Kotzé 2012:1)

Persone soos dr. Johan Otto (Gemeente Premiermyn) het deur Suid-Afrika gereis, vergaderings gehou en op die wyse is kritiek teen die besluite van die AKV en die handelinge van die Kommissie van die AKV wyd bekend gemaak. Voortvloeiend uit hierdie byeenkomste, het 'n tweede organisasie tot stand gekom, onder die naam steedsHervormers. Dit het uitgeloop op 'n formaliseringsvergadering (steedsHervormers 2012b) wat op 02 Junie 2012 te Gemeente Meyerspark plaasgevind het (vgl. steedsHervormers 2012c). By die vergadering is dr. Otto as voorsitter van steedsHervormers verkies. In Koers van Januarie lees ons:
Op grond van die huidige geloofskrisis in die Kerk besluit ons as gemeentes en lidmate van die NHKA om ons te versamel as 'n konfessionele groep met die naam 'steedsHervormers'. Hiermee wil ons te kenne gee dat:

- ons steeds onsself as lidmate van die NHKA sien en die voortsetting van die NHKA wil dien;

- $\quad$ ons nie onsself van die NHKA wil wegskeur nie;

- ons onsself vereenselwig met die teologiese tradisie van die NHKA.

As steedsHervormers wil ons getrou bly aan die trotse tradisie en geskiedenis van die Hervormde Kerk. (steedsHervormers 2012a)

Ten spyte van hierdie aanvanklike standpunt (in Januarie 2012) dat die steedsHervormers as deel van die Hervormde Kerk wil leef en werk, het dit teen Januarie 2013 dermate verander dat die Geloofsbond van Onafhanklike Hervormde Kerke gestig is. Die stigting van die Geloofsbond is voorafgegaan deur ' $n$ proses wat feitlik identies in elke 'onafhanklike' gemeente verloop het:

- Die gemeente word ingelig van afwykende leer in die Hervormde Kerk.

- Die gemeente word ingelig dat die kerk se besluit oor apartheid hulle blootstel aan regstellende aksie en dat hulle eiendom as deel van 'n restitusieprogram geëis kan word. Die gemeentevergadering besluit in beginsel dat die gemeente se eiendom 'beveilig' moet word.

- Die gemeente se predikant bedank as predikant en lidmaat van die Hervormde Kerk en herbelê sy pensioen.

- Die gemeentevergadering stig 'n vereniging en die gemeente se eiendom word na die vereniging oorgedra om dit te 'beveilig'.

- Die gemeente verklaar homself onafhanklik van die Hervormde Kerk.

Op grond van regsadvies van advokate, was gemeentes onder die indruk dat hulle outonoom bestaan en as selfstandige regspersoon besluite kan neem en kan beskik oor eiendom sonder inspraak van die Raad van Finansies, die Ringskommissie of Algemene Kommissie. Die basiese fout in hierdie proses was dat van die veronderstelling uitgegaan is dat slegs die Kerkorde ter sake is, terwyl reformatoriese kerkregering op vyf bronne berus (in volgorde van belangrikheid): Die Woord van God, Belydenisskrifte, die Kerkorde, besluite van vergaderings van die ampte en kerklike usansie.

Die hele proses van predikante wat bedank en as 'onafhanklike predikant' gemeentes bedien, vervreemding van eiendom en onafhanklikheid van gemeentes is nie net strydig met die bepalings van die Kerkorde nie, maar ook besluite van vergaderings en kerklike usansie. Dit het die situasie bykans onhanteerbaar gemaak, aangesien die Kerkorde en die opsighoudende vergaderings van die Hervormde Kerk willens en wetens verontagsaam is. Hierdie proses en aannames sal eersdaags in die hof getoets word. 


\section{Ideologiese verskille}

In sy toeligting van die Beswaarskrif tydens die Buitengewone Algemene Kerkvergadering, het dr. Johan Otto die volgende stelling gemaak:

Ek wil dit nou aan u onomwonde stel, selfs ons eerste reaksie 'n jaar gelede was nie teen die apartheid deel van die besluit wat geneem is nie. Ons het 'n probleem met die teologie wat so 'n besluit moontlik maak, ongeag die konteks waarin die besluit geneem is, dit dui op 'n nuwe teologie wat nie in die Hervormde Kerk was nie. Hierdie nuwe teologie is op twee maniere vir ons onaanvaarbaar: Die eerste is dat dit 'n bevrydingsteologie is en daaruit loop dat dit teologie vervlak tot 'n horisontale saak. (NHKA 2011:75)

In publikasies en openbare optrede van die steedsHervormers is hierdie standpunt voortdurend herhaal: Al handel Besluit 54 oor apartheid en die teologiese regverdiging van apartheid, gaan die besware teen Besluit 54 nie om apartheid nie maar om die teologie wat agter Besluit 54 sit. Is dit egter die volle prentjie? Uit die volgende voorbeelde sal dit duidelik word dat dit óók om apartheid gaan.

As eerste voorbeeld kan verwys word die Beswaarskrif wat gedien het by die Buitengewone Algemene Kerkvergadering (BAKV). Daarin word die volgende stelling gemaak:

1.6. Ons maak beswaar daarteen dat afsonderlike ontwikkeling as die vreedsame naasbestaan van mense sondermeer veroordeel word. Hierdie besluit spreek teen homself. Aan die een kant word afwysend gepraat van goedkeur/afkeur en direk daarna word ' $n$ besondere deel van 'n vorige staatsbestel se politiek tot kettery verklaar. (NHKA 2011:38)

Hieruit is dit duidelik dat die Beswaarskrif nie net die teologie agter Besluit 54 wil aanspreek nie. Afsonderlike ontwikkeling (apartheid) word gedefinieer as 'n 'vreedsame naasbestaan van mense' en die veroordeling daarvan word afgewys. Hierdie stelling van die Beswaarskrif, dat apartheid vreedsame naasbestaan bevorder, hanteer apartheid as 'n teoretiese aangeleentheid. Die praktyk van gedwonge verskuiwings, politieke moorde en ekonomiese ontmagtiging deur werkreservering word nooit aangespreek nie. Die kritiese vraag is egter: Kan ons teorie en praktyk op die wyse skei?

'n Tweede voorbeeld: Otto, as voorsitter van die steedsHervormers, skryf in Koers van Januarie 2012 die volgende: 'Naskrif: Koers is nou die amptelike mondstuk van steedsHervormers. Die elektroniese weeklikse uitgawe word eersdaags geloods' (Otto 2013:1).

'n Amptelike mondstuk van 'n organisasie publiseer sekerlik persoonlike menings van mense. Die organisasie bly egter verantwoordelik vir dit wat gepubliseer word. Indien die redakteur standpunte stel wat strydig met die organisasie of kerk se standpunte is, kan verwag word dat sulke standpunte in ' $n$ volgende uitgawe reggestel of gerepudieer sal word. Indien nie, meen ek dat 'n mens redelikerwys kan aanvaar dat die organisasie homself met die standpunte van die redakteur vereenselwig.
In Koers (Mei 2012) lees ons die volgende kritiek teen 'integrasie' en die huidige regering uit die pen van die redakteur, prof. H.G. van der Westhuizen (2012b):

Dit is natuurlik waar dat baie swartes nog, gebonde aan die kringloop van die natuur, nie vooruit dink en beplan en werk om ' $n$ ideale lewensverheffing in die toekoms te bereik nie. As hulle dan in hulle bestaansekonomie die geleentheid kry om te steel, doen hulle dit - al ís hulle ook al op ministersvlak. ... Dit ís sekerlik nie die standpunt van alle swartes nie, maar as jy langs 'n swart gemeenskap (lokasie, plakkersdorp of township) woon, wonder jy dikwels hoe 'n groot persentasie die lewenswyse van steel beoefen. ... Saambestaan op die basis van integrasie vereís die aflegging van jou lewens- en wêreldbeskouing, jou waardering van eie kultuurgoedere, jou hoogstaande arbeidsetiek, jou vooruitbeplanning en najaging van ideale en nog soveel meer.

Die waardering vir apartheid (en uitgesproke rassisme) in die amptelike mondstuk van die steedsHervormers (Oktober 2012) word nog duideliker wanneer Van der Westhuizen (2012a) die volgende skryf:

Sedert die revolusie van 1994 in ons staat het die uitdrukking van die reënboognasie herhaaldelik voorgekom en bekend geword. Waarskynlik lê die oorsprong daarvan by die staatskapelaan $\mathrm{dr}$. Desmond Tutu, die emeritus Anglikaanse aartsbiskop.

Kyk mens na die kleure van die reënboognasie ís dit allermins 'n mooi prentjie. Want swart, wat as kleur nie eers in 'n reënboog voorkom nie, wil al die ander kleure opvreet. Dit ís net swartbemagtiging vroeg en laat. Is swartes dan nie in staat om eers in 'n vrye land op meriete hulle merk te maak in die ekonomie, die staatsdiens, die provinsies, die munisipaliteite, die skole, hospitale, kolleges, universiteite, verenigings, polisie, weermag, boerdery, sport en so meer nie?

Moord, verkragting, roof, misdaad neem hand oor hand toe. Die skokkendste berigte van uitbuiting, onaanvaarbaarhede en Afrikanervolksontbening trek 'n swart streep deur 'n ordentlike beskaafde samelewing. Geestelike weë op morele hoë grond word opgebrokkel soos die slaggate ín ons gewone teerpaaie. Waar ís die prag en skoonheid, die estetiese van 'n reënboognasie? Dit ís galge humor en karikatuur.

Die gesonde eiesoortige ontwikkelingsgedagte wat die grondslag van afsonderlike ontwikkeling op staatkundige gebied was, was eerder 'n beeld van die reënboog. Wanneer die verskillende swart volke in Suider-Afrika elkeen hulle eie staat met eie kultuurinhoude, taal en lewensbestane sou hê, naas en in harmonie met Afrikaner, Kleurlinge en Indiër regerings en groeibodems, sou dit wel kon kwalifiseer as 'n reënboogstatery van Suider-Afrikaanse nasies.

Dit is ook opvallend dat Die Afrikaner, lyfblad van die Herstigte Nasionale Party (HNP), breedvoerig en in talle uitgawes aan die Besluit 54 aandag gegee het. In beriggewing in die uitgawe van 03-09 Februarie 2012, geskryf deur Anita Morkel (2012), word verwys na korrespondensie vanaf die Kommissie van die AKV aan lidmate wat, soos sy dit noem, 'beswaar maak teen die besluit dat apartheid sonde is.' Berigte in Die Afrikaner laat min twyfel dat die goedkeuring of afkeuring van apartheid ' $n$ prominente deel van die debat uitmaak. 
Dit is bekend dat verskeie van die leiersfigure van die steedsHervormers aktiewe lede van die HNP of die Afrikaner Volksparty was en is. Wanneer die webblaaie van die partye besoek word, figureer van die genoemde persone prominent. Die betrokke politieke partye is steeds ten gunste van selfbeskikking en selfregering vir die Afrikanervolk in 'n blanke gebied.

Standpunte van individuele lidmate dui ook daarop dat die saak van apartheid vir hulle van kardinale belang was en is. Die Kommissie van die AKV het verskeie briewe in ontvangs geneem, waarvan ek gedeeltes uit een as voorbeeld aanhaal (vgl. J.S. Knoesen [2012] aan die Skriba, Kommissie van die AKV, gedateer 07 September 2012):

Dit is tog mos 'n beginselsaak wat ons naby aan die hart lê en dat indien van ons blanke kerk slegs in die geringste wyse afgewyk word, sal ons sonder die minste huiwering of verdere waarskuwing uit die Kerk bedank. En ek glo, en ek kan sien, want ek is elke Sondag in die Kerk, dat daar alreeds heelwat lidmate uit die Kerk bedank het ... sodat ek en andere soos ek wat ons blanke kerkbeginsel eerste stel, die nuwe sogenaamde verwerping van apartheid met alles tot ons beskikking kan beveg. ... U valse bewering dat apartheid soos ons dit sedert die ontstaan van Suid-Afrika ken en beleef het 'nie teologies geregverdig kan word nie' is totaal onwaar en onsinnig. Apartheid is 'n leefwyse om blankes teen oorrompeling en uitwissing deur ander rasse te beskerm en het niks met teologie te doen nie. ... Julle het geen reg om nou julle voorgangers in die Kerk se beleid te herroep nie. ... Inderdaad, dit was as gevolg van die uitstekende beleid van apartheid of afsonderlike ontwikkeling dat die Kerk tot stand gekom het en gegroei het tot die Kerk wat dit vandag is.

Die brief, wat in my besit is, spreek vanself. Miskien net die een opmerking: Die lidmaat beweer dat die Hervormde Kerk 'het tot stand gekom en gegroei as gevolg van die uitstekende beleid van apartheid.' 'n Duideliker voorbeeld van volksteologie en burgerlike godsdiens sal mens nêrens vind nie.

Op 02 Junie 2012 het die steedsHervormers (2012e) 'n status confessionis teen die Hervormde Kerk uitgereik. In die dokument word die volgende ten opsigte van die kerk se besluit oor apartheid gestel: 'Die BAKV se besluit om 54/69 te behou, verloën die evangelie van Jesus Christus as die opgestane HERE.' Die Staat van Belydenis is tydens die formaliseringsvergadering deur die Geloofsbond van Hervormde Gemeentes bekragtig en gehandhaaf. Die teologiese implikasies van Saak 2 in die Staat van Belydenis is ingrypend:

- Die Hervormde Kerk se besluit dat apartheid nie teologies regverdig kan word nie, verloën die evangelie van Jesus Christus as opgestane Here.

- Die Hervormde Kerk se besluit dat apartheid nie teologies regverdig kan word nie, is strydig met die Bybel en die belydenis van die kerk.

- Die Hervormde Kerk se besluit dat apartheid nie teologies regverdig kan word nie, beteken dat die Hervormde Kerk nie meer bely dat Jesus die Verlosser is nie.
Prakties beteken dit die volgende: Die Hervormde Kerk, as gevolg van sy besluit oor apartheid, het as kerk van Jesus Christus ophou bestaan. Daarom beskou die Geloofsbond homself as die ware voortsetting van die Hervormde Kerk. Verder: Indien 'n lidmaat of ampsdraer van die Hervormde Kerk Besluit 54 steun en van mening is dat die Hervormde Kerk in die verlede gefouteer het om apartheid teologies te begrond, verloën hy of sy Jesus Christus.

Die vraag is dus: As die lyne so skerp tussen die 'Christusloënaars' en 'regsinniges' getrek word, is gesprek nog enigsins moontlik tussen die Hervormde Kerk en die Geloofsbond van Hervormde Gemeentes? Is dit moontlik om in gesprek te wees, wanneer jou standpunt oor apartheid bepaal of jy Christus verloën of bely as Verlosser?

Dat die Staat van Belydenis ook om apartheid gaan, is bevestig deur 'n uitspraak waarin die Adjunk-Persombudsman, mnr. Johan Retief (2012), wat op 01 Augustus 2012 teen adv. Renette du Plessis bevind het. In haar voorlegging het Du Plessis beweer dat die besware van lidmate teen Besluit 54 nooit oor apartheid gegaan het nie, maar eerder prosedureel en teologies van aard was. Sy het ook 'n saak daarvoor uitgemaak dat die woord 'apartheid' nie in die Staat van Belydenis gebruik word nie.

In sy beredenering van die saak het mnr. Retief moeite gedoen om die wyer konteks in oënskou te neem, deur onder andere te verwys na opmerkings van ds. Gawie Wolmarans wat op internet verskyn het:

Ek neem ook hier in ag dat ds. Gawie Wolmarans van die steedsHervormers onlangs op die internet geskryf het: 'Ek het geen twyfel daaroor dat die notulering van teenstemme oor Besluit 54 (die gewraakte besluit) gedryf is deur 'n woede van die afgevaardigdes oor die indruk dat die eerbare politieke bedoelings en optrede van ons ouers en voorouers nou amptelik deur die Kerk tot sonde verklaar is nie.' (Retief 2012)

Daarbenewens wys hy ook op teenstrydighede in Du Plessis se eie argumentvoering. Die bevinding van die AdjunkPersombudsman lui dan soos volg:

In haar klag skryf Du Plessis: 'Ek het nie objektiewe beriggewing deur mnr. Neels Jackson verwag nie. Ek het egter nie verwag dat hy die waarheid so blatant sal verdraai nie.' Sy sê ook: 'Vir sover mnr. Jackson wil voorgee dat die dag se verrigtinge en veral die uitroep van die status confessionis met apartheid te doen het, verkondig hy ' $\mathrm{n}$ absolute leuen.' Ek het bevind dat Jackson geregverdig was in sy beriggewing. Bogenoemde kwetsende opmerkings was daarom ongelukkig, ongevraag en sonder basis - en ek meen dat Du Plessis hom ' $\mathrm{n}$ verskoning verskuldig is of, op die minste, dat sy haar woorde sal terugtrek. Ek het egter geen jurisdiksie oor haar nie en kan haar daarom nie dwing om dit te doen nie. (Retief 2012, [outeur se beklemtoning])

Ek kan, op grond van historiese navorsing en ook dokumente wat vrylik op die internet beskikbaar is, nie anders as om tot die gevolgtrekking te kom dat die vurk in die pad nie net teologies van aard is nie, maar ook ideologies. 


\section{Verskille in teologiese denke}

Sedert die 69e AKV (2010) is Hervormde dosente verbonde aan die Fakulteit Teologie, àan die Universiteit van Pretoria elkeen persoonlik uitgewys in terme van afwykende teologie. Daarvan was ekself getuie. By 'n geleentheid te Gemeente Zeerust op 17 Februarie 2013, waar ekself en dr. Johan Otto as sprekers opgetree het, het hy moeite gedoen om elkeen van die huidige dosente se afwykende teologie aan die gemeente te openbaar. In my eie geval, is aangetoon dat ek afwyk van die tradisionele volkskerklike apostolaat deur missionale kerkwees te bevorder.

Soos reeds aangetoon, word beweer dat dit nie om apartheid gaan nie maar om teologiese dwaling wat in die kerk teenwoordig is. So lees ons in die onafhanklikheidsverklaring van Gemeente Premiermyn op 22 Oktober 2012:

Die Hervormde Kerk het veral vanaf die 90-jare van die vorige eeu die Bybels-reformatoriese teologie begin versaak. Aangevuur deur die drif om deel van die ekumeniese wêreld te word, en dit ten koste van ons Reformatoriese erfenis, is die Kerk se teologie vervlak. Hierdie wegbeweeg word direk toegeskryf aan die afwykende teologiese tendense ten opsigte van die Skrif, die Belydenis, asook die Reformatoriese liturgie van die Kerk. Hierdie afwykende tendense word in snelgroeiende maat waargeneem in die Kerk se teologiese arbeid, publikasies en elektroniese media, uitsprake van veral geleerde teoloë en vergaderings. (vgl. NHKA 2012b)

Die fundamentele argument wat aangevoer word, is dat Besluit 54 vanuit die bevrydingsteologie begrond word. Dit word soos volg geformuleer:

Ons maak beswaar teen die inhoud van besluit 54 van die 69 ste AKV. Ons het dit teen die teologiese inhoud van die besluit, asook die haelgeweerskoot-effek van 'n besluit wat duidelik nie goed oorweeg is nie. Ons teologiese besware hou met die volgende verband:

- Die besluit bring die bevrydingsteologie in die Kerk in.

- Daar word 'n vreemde evangelie verkondig wat nét die horisontale in ag neem.

Daar word ' $n$ vreemde mensbeeld in die besluit verwoord. (steedsHervormers 2012f)

Die kerk se teologiese dosente is daarvan beskuldig dat hulle die Bybels-reformatoriese teologie versaak het en nou 'n vrysinnige en/of bevrydingsteologie aanhang en propageer. Die mening word dikwels uitgespreek dat dit die dosente se 'bevrydingsteologie' was wat die 'afwykende' besluite van die AKV voorberei en aangestook het. Weereens sal enkele voorbeelde die saak illustreer:

Die optrede van ons as steedsHervormers binne die Kerk het ' $n$ lang aanloop gehad en het alles met teologie en weinig met mag of politiek te make. Op teologiese vlak moet die wending in die Kerk op twee vlakke aangedui word. Aan die een kant was daar al hoe meer ' $n$ vrysinnigheid in die teologie te bespeur, met die boek van AG van Aarde as die duidelikste baken van ' $n$ teologie wat geloof ondergrawe. Nie net die maagdelike verwekking van Jesus is in die spervuur nie, maar ook die opstanding. Die kanon word as oop hanteer (met ander woorde boeke soos die Thomas-evangelie word byvoorbeeld gesien as 'n belangrike bron vir teologie-beoefening), en die band tussen Ou Testament en Nuwe Testament word ontken. Teen hierdie agtergrond is dit belangrik om net weer te stel dat dit die nuwe teologie is, wat die besluite wat geneem is, moontlik maak. Die Kerk se nuwe teologie, soos aangedryf deur die meeste van die dosente, het ook sy oorsprong in die vrysinnigheid en humanisme wat so eie is aan die huidige fakulteit aan ' $n$ staatsinstansie.

Besluit 54/69 kon slegs geneem word, indien 'n sekere soort teologie oorheers. Die bevrydingsteologie wat op die mens fokus, is die agtergrond van anti-apartheidsbesluite in die verlede in ander kerkgroepe.

Die opvolgbesluit herroep ook enige ondersteuning aan afsonderlikheid in die verlede, die saak van bevrydingsteologie staan soveel sterker in die nuwe besluit. (vgl. steedsHervormers 2012c)

Die implikasie van hierdie argument is dat Besluit 54 nie vanuit 'n Bybels-reformatoriese teologie begrond kan word nie. Dit is wel korrek dat daar, histories gesproke, vanuit die bevrydingsteologie skerp kritiek teen apartheid uitgespreek is. Dit is tegelykertyd foutief om te redeneer dat teologiese kritiek teen apartheid beperk is tot bevrydingsteologie. Na die Tweede Wêreldoorlog het talle teoloë, wat op geen manier as bevrydingsteoloë geklassifiseer kan word nie, skerp kritiek teen die teologiese regverdiging van apartheid uitgespreek. 'n Oorsig van dié kritiek kan gevind word in Hofmeyr, Lombaard en Maritz (2001) asook Van Butselaar (2001).

Die kritiese vraag is: Hoe reflekteer ons teologies oor ongeregtigheid wat tydens die apartheidsjare (en wat die kerk reeds in 2001 erken en bely het) plaasgevind het? Hoe praat ons binne die Suid-Afrikaanse konteks oor gedeeltes in die Ou- en Nuwe Testament wat onomwonde die eis tot sosiale geregtigheid stel? En wat maak ons daarmee dat Calvyn besonder baie oor sosiale geregtigheid geskryf het (bv. sy De Clementia), wat opgevolg is deur Theodor Beza se De iure magistratuum in subitos, et officio subitorum erga magistratus (vgl. Dreyer 1996)? 'n Mens hoef maar net iets te lees soos dr. William Innes (1983) se gepubliseerde proefskrif Social concern in Calvin's Geneva, om te besef dat sosiale geregtigheid volledig deel was van die reformasie (vgl. ook Dreyer 1995:24-25).

Dit is fundamenteel belangrik dat 'n kerk wat homself as reformatories beskou, altyd weer hervorm. Hervorming kan nie lukraak geskied nie. Kerkhervorming kan alleen op grond van die Skrif en grondige teologies nadenke geskied. Daarom is dit noodsaaklik dat teologiese standpunte van die verlede deurlopend krities evalueer en verander word, indien nodig. 'n Klassieke voorbeeld hiervan is die Hervormde Kerk se besluit in 1976 om vrouens tot die amp toe te laat.

Om krities met die verlede en teologiese uitsprake om te gaan, is nie per definisie bevrydingsteologie nie - inteendeel - dit is per definisie reformatoriese teologie. Dit is veral só, waar ' $n$ kerk erns maak met die reformatoriese slagspreuk ecclesia reformata, semper reformanda. 
Die beskuldiging van dwaalleer is so wyd deur die kerk versprei, dat dit die dosente van die Hervormde Kerk genoop het om op 18 Julie 2011 'n verklaring uit te reik, wat elkeen met sy of haar handtekening bevestig het. Dit is ook opgeneem in die Agenda van die 70e AKV:

Ons, die ondergetekende dosente, bevestig met ons handtekening dat ons steeds, soos in die verlede, die leer van die kerk, soos uitgedruk in die drie Ekumeniese Geloofsbelydenisse en die Drie Formuliere van Eenheid, van harte onderskryf. (NHKA 2013:83-84)

Die verklaring deur die dosente het weinig daartoe bygedra om bewerings van dwaalleer te besweer. Dit het na die Buitengewone Algemene Kerkvergadering in intensiteit toegeneem. Een voorbeeld sal dit voldoende illustreer:

'n Klagskrif is op 18 Junie 2012 by die Kommissie van die AKV teen prof. A.G. van Aarde ingedien. Die klagskrif is deur die Sekundus Kommissie van die AKV na die klaers terugverwys, aangesien daar nie 'n broederlike gesprek met prof. Van Aarde gevoer is nie. Op 06 Augustus 2012 het die broederlike gesprek tussen adv. Renette du Plessis, br. Johann Hurter en prof. A.G. van Aarde te Gemeente Wapadrant plaasgevind (vgl. notule van die broederlike gesprek soos opgeneem in NHKA 2012a:13-17). Adv. Du Plessis se dogter was ook teenwoordig.

Tydens die broederlike gesprek is indringende vrae aan Van Aarde gestel. Sy navorsing oor die historiese Jesus het pertinent aan die orde gekom. Volgens die notule van die verrigtinge is daar herhaaldelik aan prof. Van Aarde 'gevra of hy glo in die opstanding.' Hy het herhaaldelik die geloofsbelydenis uitgespreek:

dat hy glo met sy hele wese in Jesus Christus, ware God en ware mens en in sy opstanding uit die dood. Dit is 'n geloofsbelydenis wat egter nie histories bewysbaar is nie. (NHKA 2012a:16)

Op die vraag of die klaers sy geloofsbelydenis aanvaar, was die antwoord dat hulle dit aanvaar, maar nie seker is dat hulle dieselfde onder geloof verstaan as Van Aarde nie. Direk na afloop van die slotgebed, wou Van Aarde die klaers groet. Adv. Du Plessis en br. Hurter het hom 'n handdruk gegee. Toe hy sy hand na mej. Du Plessis uitsteek was haar woorde 'ek is jammer professor, maar ek skud nie hande met die duiwel nie' (NHKA 2012a:17).

Dit is opvallend dat die klaers probeer aantoon het dat die kerk se geloof nie metafories verstaan moet word nie, maar letterlik en histories. Van Aarde het probeer aantoon dat 'metafories' nie beteken dat iets onwaar is nie, maar dat een saak in terme van 'n ander beskryf en verstaan word.

Uit die notule word die prinsipiële verskille in Skrifbeskouing tussen die klaers en Van Aarde duidelik. Die klaers se argumentasie vertoon 'n sterk konfessionalistiese Skrifbeskouing wat geen ruimte laat vir die beoefening van kritiese teologie nie.

\section{Enkele kerkregtelike opmerkings}

In Beeld van 30 Julie 2013 verskyn 'n artikel, geskryf deur Neels Jackson, onder die opskrif '13 Kerke wat NHK los, begin nuut' (Jackson 2013). Die berig is geskryf na aanleiding van die eerste vergadering wat die Geloofsbond van Hervormde Gemeentes wat van 28-30 Julie 2013 te Gemeente Tuine plaasgevind het. Hy skryf soos volg:

Dertien gemeentes wat die afgelope jaar van die Hervormde Kerk weggebreek het, het gister 'n 'nuwe begin' gemaak met die eerste vergadering van die Geloofsbond van Hervormde Gemeentes. Dié vergadering is gehou in die gemeente PretoriaTuine, die eerste gemeente wat besluit het om hom van die Hervormde Kerk los te maak.

Dr. André Botma, voorsitter, het herhaaldelik beklemtoon dat dié vergadering nie neerkom op die stigting van 'n nuwe kerk nie. Die onderskeie gemeentes behou hul onafhanklikheid, maar die Geloofsbond sal die samewerking tussen die gemeentes reël. Die Geloofsbond het hom gister verbind tot die Bybel en die belydenisskrifte. Botma het aan die begin van die vergadering gesê daar is twee goed waaroor daar konsensus is. Om by die Geloofsbond in te skakel moet ' $n$ gemeente die belydenisse onderskryf en die gedagte van 'n volkskerk aanvaar as ' $n$ manier om die evangelie uit te dra.

Daar is ook besluit om die Staat van Belydenis te handhaaf wat beswaarde lidmate in 2012 teenoor die Hervormde Kerk verklaar het. Dié Staat van Belydenis het ' $\mathrm{n}$ rits klagtes oor die Hervormde Kerk se teologie geopper. Dit kom onder meer daarop neer dat die kerk die evangelie van verlossing in Jesus Christus verruil het vir ' $n$ horisontale teologie. Dié beskuldiging is herhaaldelik deur die Hervormde Kerk verwerp.

Die Geloofsbond het ' $n$ komitee aangewys wat 'n kerkorde vir die Geloofsbond moet opstel en 'n kuratorium wat die opleiding en toelating van predikante moet hanteer. Geloofsbondvergaderings gaan jaarliks gehou word. (Jackson 2013)

In die aanloop tot die vergadering van die Geloofsbond, is daar deurlopend aan die Kommissie van die AKV gestel dat die 'onafhanklike' gemeentes, steeds deel van die Hervormde Kerk is. Die Kommissie se interpretasie van die gebeure was dat dit neerkom op ' $n$ kerklike afskeiding en dat die gemeentes, predikante en lidmate wat hulleself 'onafhanklik' verklaar, nie meer regtens deel van die Hervormde Kerk is nie. Hulle het hulleself deur hulle optrede afgesny van die kerk. Immers, volgens die Handboek van die Afrikaanse Taal en die Oxford Dictionary beteken die woorde 'onafhanklik/ independent' 'vry, selfstandig, nie-onderworpe, selfregerend, outonoom, selfregulerend en finansieel selfversorgend.' Die gebeure van 28-30 Julie 2013 bevestig die standpunt van die Kommissie. In hierdie persberig is die volgende sake opvallend:

- Daar word nie 'n nuwe kerk gestig nie. Dit is 'n Geloofsbond van onafhanklike gemeentes wat hulleself onafhanklik van die NHKA verklaar het. Dit beteken dat elke gemeente op sy eie 'n onafhanklike kerk vorm. Daar is dus vir die huidige nie 'n sinodale verband nie. Dit word uitdruklik verwoord met die term ecclesia completa wat telkens gebruik word. Dit is 'n tipiese kongregasionalistiese en independentistiese model van kerkwees. 
- Die 13 betrokke gemeentes (kerke) verbind hulleself aan mekaar op grond van die Bybel as die Woord van God, die Drie Formuliere van Eenheid en die volkskerklike beginsel ('n kerk vir Afrikaners).

- Die Staat van Belydenis word die onderskeidende kriterium wat hulle van die Hervormde Kerk onderskei. Dit is 'n dokument wat bepaalde teologiese uitgangspunte uitspel. Daarmee saam beoog hulle 'n eie Kuratorium, teologiese opleiding en ordening van predikante. (Jackson 2013)

Ek meen dat daarmee die proses van afskeiding voltrek is. Daar kan geen twyfel meer wees dat die gemeentes (kerke) hulleself buite die Hervormde Kerk gestel het nie. Die gebeure rondom die stigting van die Geloofsbond van Hervormde Gemeentes, dui daarop dat die betrokke gemeentes en lidmate hulle van die Hervormde Kerk afgeskei het. Die vestiging van 'n onafhanklike kerklike struktuur, 'n eie identiteit, naam en dokumente met konfessionele uitgangspunte kan nie anders verstaan word as 'n kerklike afskeiding nie.

Daar is talle voorbeelde in die wêreld waar gemeentes hulleself 'onafhanklik' verklaar om dan net weer nuwe verhoudings met ander gemeentes en kerke te vestig. In die geskiedenis van gereformeerde kerke bestaan daar talle voorbeelde hiervan, onder andere in Skotland en Nederland in die negentiende eeu. Die Gereformeerde Kerke (Vrijgemaakt) in Nederland se 'vrymaking' van die Gereformeerde Sinode in 1944 is ' $n$ tipiese voorbeeld.

Ook in die VSA, met die Restoration Movement aan die begin van die twintigste eeu en die vestiging van die Independent Churches in 1930, het onafhanklike kerke 'n algemene verskynsel geword. Die beweging was gekant teen modernistiese tendense in die teologie en gevestigde kerke. Volgens Wikipedia (s.a.), het die onafhanklike kerke in die VSA in 1996 die Independent Fundamental Churches of America (IFCA) gevorm.

Onafhanklike kerke wêreldwyd vertoon 'n kongregasionalistiese struktuur. Gemeentes funksioneer selfstandig van mekaar en enige binding aan ander gemeentes vind plaas op grond van die belydenisskrifte. Sulke gemeentes kom dan ooreen om 'n bepaalde struktuur van samewerking te skep. Ek is van mening dat die Geloofsbond van Hervormde Gemeentes tipies kongregasioneel, konfessionalisties en independentisties funksioneer.

Die Geloofsbond van Hervormde Gemeentes het ook besluit dat die Kerkorde van die NHKA vir die interim in gemeentes sal geld, maar dat daar gekyk sal word na 'n nuwe kerkorde. Die oomblik as 'n eie kerkorde ter sprake kom, praat ons van 'n eie en selfstandige kerkverband. 'n Kerkorde verbind gemeentes de iure en organies aan mekaar. Die kerkorde, soos die belydenisskrifte, gee uitdrukking aan kerklike eenheid. Wanneer 'n ampsdraer of gemeente in sy besluite en handelinge die kerkorde negeer, word die eenheid met die res van die gemeentes opgehef. Dit is die implikasie van die proponentsformule asook die vrae wat aan lidmate gevra word tydens die hulle openbare belydenis van geloof.
Kerklike eenheid kom primêr tot uitdrukking in die kerk se belydenis. In Ordereël 1 van die Kerkorde (NHKA 2010:1-2) is dit baie duidelik dat die belydenis en leer van die Hervormde Kerk ook in teologiese onderrig en uitsprake reflekteer. Wanneer die Geloofsbond dit uitdruklik stel dat daar reeds oor teologiese sake ooreengekom is, dat 'n eie teologiese opleiding beplan word en dat die AKV se besluite berus op afwykende teologie wat die opstanding van Christus verloën, verbreek ook dít die eenheid met die Hervormde Kerk.

Ek is dus van mening dat die Kommissie van die AKV korrek was in sy interpretasie van die Kerkorde, dat lidmate wat hulle met die Geloofsbond identifiseer en daarvan lid is, de iure opgehou het om lidmate van die Hervormde Kerk te wees. Die standpunt dat lidmate eers ophou om lidmate van die kerk te wees as hulle self so te kenne gee, hou nie water nie. Dit berus op ' $n$ institusionele kerkbegrip. 'n Lidmaat kan ook deur sy optrede, sonder om formeel te bedank, sy of haar lidmaatskap van die kerk tot niet maak deur strydig met die Kerkorde te handel en/of die leer van die kerk te verwerp.

Deur 'n struktuur onafhanklik van die Hervormde Kerk te vestig wat bindende besluite neem ten opsigte van leer, teologiese opleiding en orde, het die Geloofsbond van Onafhanklike Hervormde Kerke as 'n selfstandige 'kerk' los van die Hervormde Kerk gekonstitueer.

\section{Erkenning Mededingende belange}

Die outeur verklaar dat hy geen finansiële of persoonlike verbintenis het met enige party wat hom nadelig kon beïnvloed in die skryf van hierdie artikel nie.

\section{Literatuurverwysings}

Calvijn, J., [1559] 1949, Institutio christianae religionis, transl. A. Sizoo, Naamloze Vennootschap WD Meinema, Delft.

Dreyer, P.S., 1974, Inleiding tot die filosofie van die geskiedenis, HAUM, Pretoria.

Dreyer, W.A., 1995, 'Kerk, volk en owerheid. 'n Hervormde perspektief', DD-proefskrif, Departement Kerkgeskiedenis, Universiteit van Pretoria.

Dreyer, W.A., 1996, 'Enkele aspekte van Beza se politieke teorie, soos verwoord in sy De iure magistratuum', HTS Teologiese Studies/Theological Studies 52(4), 10011013. http://dx.doi.org/10.4102/hts.v52i4.1587

Dreyer, W.A., 2011a, 'Enkele gedagtes oor kerkwees in die 21e eeu', openingsrede by die opening van die Hervormde Teologiese Kollege, Pretoria, Februarie.

Dreyer, W.A., 2011b, 'Histories-vergelykende ekklesiologie - Oppad na 'n omvattende Praktiese Ekklesiologie', HTS Teologiese Studies/Theological Studies 67(3), Art. \#1083, 8 pages. http://dx.doi.org/10.4102/hts.v67i3.1083

Dreyer, W.A., 2011d, "n Multidissiplinêre benadering tot Praktiese Ekklesiologie', HTS Teologiese Studies/Theological Studies 67(2), Art. \#1088, 9 pages. http://dx.doi. org/10.4102/hts.v67i2.1088

Dreyer, W.A., 2011e, 'Prakties-teologiese ekklesiologie en bedieningspraktyk, met verwysing na die Ned. Hervormde Kerk van Afrika', PhD proefskrif, Departement Praktiese Teologie, Universiteit van Pretoria, beskikbaar by http://upetd.up.ac.za/ thesis/available/etd-10072011-085454/unrestricted/00front.pdf

Dreyer, W.A., 2013a, 'Die Hervormde Kerk en apartheid', HTS Teologiese Studies/ Theological Studies 69(1), Art. \#1944, 7 pages. http://dx.doi.org/10.4102/hts. v69i1.1944

Dreyer, W.A., 2013b, 'Missional ecclesiology as basis for a new church order: A case study', HTS Teologiese Studies/Theological Studies 69(1), Art. \#1368, 5 pages. http://dx.doi.org/10.4102/hts.v69i1.1368

Gregan, S.H., 2009, 'Nog 'n Afrikaner bastion val', in Afrikaner Volksparty, besigtig 09 Julie 2013, by http://afrikanervolksparty.org/index.php?option=com content\& view=article\&id=369:nog-n-afrikaner-bastion-val\&catid=16:artikels\&Itemid=12 
Hofmeyr, J.W., Lombaard, C.J.S. \& Maritz (eds.), 2001, 1948 plus 50 years: Theology, apartheid and the church - Past, present and future, IMER Publishers, Pretoria.

Innes, W., 1983, Social concern in Calvin's Geneva, Pickwick Publication, Pennsylvania.

Jackson, N., 2013, '13 Kerke wat NHK los begin nuut', Beeld, 30 Julie, besigtig 31 Julie 2013, by http://www.beeld.com/nuus/2013-07-30-13-kerke-wat-nhk-los-beginnuut

Knoesen, J.S., 2012, 'Verwerping van die beginsel van ons Blanke kerk', korrespondensie aan die Skriba van die Kommissie van die AKV, 07 September, Argief van die Nederduitsch Hervormde Kerk, Pretoria.

Kotzé, H.G.S., 2012, 'Red die Hervormde Kerk se karakter', Koers, Februarie 2012 besigtig 07 Julie 2013, by http://www.steedshervormers.co.za/koers/koersfebruarie-2012/page-13?showall=

Lines, C., 2006, 'God se Gees was daar', Konteks van die Hervormde Kerk 17(7) Rekordnommer \#31649, 2 bladsye, Argief van die Nederduitsch Hervormde Kerk, Pretoria.

Manie, 2012, 'Leraar of leunaar', in Noordoos-Transvaalse Boerekommando, besigtig 12 Julie 2013, by http://notbk.co.za/news/78/15/Leraar-of-Leunaar.html\#1

Morkel, A., 2012, 'Gevaarligte van tug begin teen steedsHervormers begin flikker', Die Afrikaner, 03-09 Februarie, besigtig 12 Julie 2013, by http://issuu.com/ neogenocide/docs/die-afrikaner-februarie-2012.

Nederduitsch Hervormde Kerk van Afrika (NHKA), 1997, 'Kerkorde van die Nederduitsch Hervormde Kerk van Afrika', Argiefbewaarplek van die Nederduitsch Hervormde Kerk van Afrika, Pretoria.

Nederduitsch Hervormde Kerk van Afrika (NHKA), 2010, 'Kerkorde van die Nederduitsch Hervormde Kerk van Afrika', Argiefbewaarplek van die Nederduitsch Nederduitsch Hervormde Kerk van Af
Hervormde Kerk van Afrika, Pretoria.

Nederduitsch Hervormde Kerk van Afrika (NHKA), 2001, 'Notule van die 66e Algemene Kerkvergadering', Argiefbewaarplek van die Nederduitsch Hervormde Kerk van Afrika, Pretoria.

Nederduitsch Hervormde Kerk van Afrika (NHKA), 2004, 'Agenda van die 67e Algemene Kerkvergadering', Argiefbewaarplek van die Nederduitsch Hervormde Kerk van Afrika, Pretoria.

Nederduitsch Hervormde Kerk van Afrika (NHKA), 2006, 'Handelinge van die Kommissie van die AKV', Argiefbewaarplek van die Nederduitsch Hervormde Kerk van Afrika, Pretoria.

Nederduitsch Hervormde Kerk van Afrika (NHKA), 2007, 'Identiteit en relevansie van die kerk in die 21e eeu. Herderlike Brief van die Kommissie van die Algemen Kerkvergadering', Argiefbewaarplek van die Nederduitsch Hervormde Kerk van Afrika, Pretoria.

Nederduitsch Hervormde Kerk van Afrika (NHKA), 2010, 'Besluitebundel van die 69e Algemene Kerkvergadering', Argiefbewaarplek van die Nederduitsch Hervormde Kerk van Afrika, Pretoria.

Nederduitsch Hervormde Kerk van Afrika (NHKA), 2011, 'Notule van die Buitengewone Algemene Kerkvergadering', Argiefbewaarplek van die Nederduitsch Hervormde Kerk van Afrika, Pretoria.

Nederduitsch Hervormde Kerk van Afrika (NHKA), 2012a, 'Agenda van 'n buitengewone vergadering van die Moderamen, 27 Augustus 2012', Argiefbewaarplek van die Nederduitsch Hervormde Kerk van Afrika, Pretoria.

Nederduitsch Hervormde Kerk van Afrika (NHKA), 2012b, Hervormde Kerk Permiermyn word onafhanklik, besigtig 08 Julie 2013, by http://www.steedshervormers co.za/verklarings-steedshervormers/145-hervormde-kerk-premiermyn-wordonafhanklik.html

Nederduitsch Hervormde Kerk van Afrika (NHKA), 2013, 'Agenda van die 70e Algemene Kerkvergadering', Argiefbewaarplek van die Nederduitsch Hervormde Kerk van Afrika, Pretoria.

Otto, J., 2012, 'Boodskap van die Voorsitter', Koers, Januarie, besigtig 11 Julie 2013 , by http://www.steedshervormers.co.za/koers/84-koers-januarie-2012. html? showall=\&start=3.
Otto, J., 2013, 'Reaksie deur dr Johan Otto op omsendskrywe 17: Riglyne aan kerkrade teen die agtergrond van kerklike afskeiding in steedsHervormers, besigtig $10 \mathrm{Julie}$ 2013, by http://www.steedshervormers.co.za/protes/151

Pont, A.D., 2013a, 'Facebook inskrywing gemaak op 30 April 2013', besigtig 15 Julie 2013, by https://www.facebook.com/permalink.php?storyfbid=46123254062546 0\&id $=118368828245168$

Pont, A.D., 2013b, 'Probleemposisie van predikante en gemeentes in besluite van die AKV teen-oor Bybel, Belydenis en Kerkorde', in steedsHervormers, besigtig op 10 Julie 2013, by http://www.steedshervormers.co.za/protes/142-probleemposisievan-predikante-en-gemeentes-in-besluite-van-die-akv-teen-oor-bybel-belydenisen-kerkorde.html

Retief, J., 2012, 'Renette du Plessis vs. Beeld', in Press Council, besigtig 16 Julie 2013 by http://presscouncil.org.za/Ruling/View/renette-du-plessis-vs-beeld-2341

Ricoeur, P., 2004, Memory, history, forgetting, transl. K. Blamey \& D. Pellauer, Chicago University Press, Chicago. http://dx.doi.org/10.7208/ chicago/9780226713465.001.0001

SteedsHervormers, 2012(a), 'Aan die Kommissie van die Algemene Kerkvergadering', besigtig geen datum, by http://www.steedshervormers.co.za/koers/84-koersjanuarie-2012. html? showall=\&start $=1$

SteedsHervormers, 2012(b), 'Formaliseringsvergadering', besigtig 13 Julie 2013, by http://www.steedshervormers.co.za/formaliserings-vergadering.htm

SteedsHervormers, 2012c, 'Inligtingstuk 2012', besigtig 13 Julie 2013, by http://www. steedshervormers.co.za/verklarings-steedshervormers/92-inligtingstuk-2012. html.

SteedsHervormers, 2012(d), 'Reaksie deur dr Johan Otto om omsendskrywe 17: Riglyne aan kerkrade teen die agtergrond van kerklike afskeiding', besigtig 05 Julie 2013, by http://www.steedshervormers.co.za/protes/151

SteedsHervormers, 2012(e), Staat van Belydenis, besigtig 17 Julie 2013, by http:// steedshervormers.co.za/formaliserings-vergadering/121-staat-van-belydenis. $\mathrm{htm}$

SteedsHervormers, 2012(f), Waarteen maak ons beswaar?, besigtig 05 Julie 2013, by http://www.steedshervormers.co.za/protes/waarteen-maak-ons-beswaar

SteedsHervormers 2013, Bondsverklaring 26 Januarie 2013, besigtig 06 Julie 2013 , by http://www.steedshervormers.co.za/verklarings-steedshervormers/155Geloofsbondsverklaring-26-januarie-2013-01-27.htm

Steenkamp, J.J., 1995, " $\mathrm{n}$ Eietydse Getuienis op Hervormingsondag', dokument versprei deur 'Die Verbond', Argiefbewaarplek van die Nederduitsch Hervormde Kerk van Afrika, Pretoria.

Van Butselaar, G.J., 2001, 'In the context of Europe', in J.W. Hofmeyr, C.J.S. Lombaard \& P.J. Maritz (eds.), 1948 plus 50 years: Theology, apartheid and the church - Past, present and future, pp. 150-168, IMER Publishers, Pretoria.

Van der Merwe, F., 2012, 'Klag teen Prof J. Buitendag', Koers, Februarie, besigti 10 Julie 2013, by http://www.steedshervormers.co.za/koers/136-koersfebruarie-2012.html?showall=\&start=8

Van der Merwe, B. \& Oelofse, M., 2011, 'Teologiese twis rondom sinodale koersveranderinge in die Nederduitse Gereformeerde Kerk 1982-1990, Historia 56(2) 154-168, besigtig 29 Julie 2013, by http://www.scielo.org.za/scielo. php?script=sci_arttext\&pid=S0018-229X2011000200009\&lng=en\&nrm=iso

Van der Westhuizen, H.G., 2012a, 'Die reënboognasie', Koers, Oktober, besigtig 06 Julie 2012, by http://www.steedshervormers.co.za/koers/148-koers-oktober-2012. html? Showall $=\&$ start $=7$

Van der Westhuizen, H.G., 2012b, 'Swartes moet steel', Koers, Mei, besigtig 07 Julie 2013, by http://www.steedshervormers.co.za/koers/112-koers-mei-2012. html?showall=\&start=5

World Alliance of Reformed Churches (WARC), 2006, 'Post visit resolutions, 8 Junie 2006', Argiefbewaarplek van die Nederduitsch Hervormde Kerk van Afrika, Pretoria.

Wikipedia, s.a., Independent fundamental Churches of America, viewed no date, fromhttp://en.wikipedia.org/wiki/Independent_Fundamental_Churches_of_ America 